[Vicino Oriente XIX (2015), pp. 185-218]

\title{
KHALET AL-JAM'A \\ A MIDDLE BRONZE AND IRON AGE NECROPOLIS NEAR BETHLEHEM (PALESTINE)
}

\begin{abstract}
Lorenzo Nigro - Daria Montanari - Sapienza University of Rome
Mohammed Ghayyada - Jehad Yasine - Ministry of Tourism and Antiquities of Palestine

During Spring 2013, the MOTA-DACH Office of Bethlehem was informed of the retrieval of a tomb during the construction of an industrial area roughly $2.2 \mathrm{Km}$ south-east of the Basilica of the Nativity on the Hindaza hill slope called Khalet al-Jam'a. Palestinian archaeologists recovered a number of items identifying there a multi-period necropolis. The site was the object of a rescue excavation in the following Spring 2014. Eleven tombs and their fittings were rescued and recovered in the MOTA storerooms. In May 2015, a joint Italian-Palestinian team preliminary surveyed the necropolis and recorded its finds, planning a future systematic exploration. At a provisional exam, $K J$ necropolis was in use during Intermediate Bronze Age (EB IV), Middle Bronze Age and, successively, through the whole Iron Age.
\end{abstract}

Keywords: Bethlehem; necropolis; Early Bronze IV; Middle Bronze; Iron Age

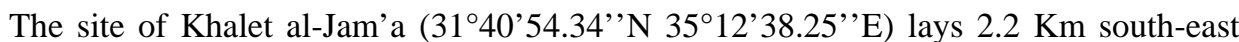
from the center of Bethlehem (fig. 1), on the south-eastern slope of the hill of Hindaza, where a large area was used as cemetery in pre-classical antiquity. The geomorphology is characterized by a gently emerging limestone bedrock that shelves from a maximum elevation of around $700 \mathrm{~m}$ a.s.l., on the hill top, to the $660 \mathrm{~m}$ contour line on a central terrace on the hill flanks overlooking Wadi Artas.

\section{THE DISCOVERY}

In Spring 2013, during works for the construction of an industrial park promoted and developed by a French-Palestinian partnership, a bulldozer accidentally exposed a rock-cut tomb. The Palestinian Tourist Police, having intercepted some items, promptly informed the MOTA-DACH Office of Bethlehem which identified the plundered tombs, and, in Spring 2014, carried out a salvage excavation in order to survey the tombs and recover their fittings. In the meantime, after several negotiations with the construction firm, building activities were stopped in the still preserved western part of the necropolis.

In Spring 2015, the MOTA-DACH and Sapienza University of Rome formed a joint team $^{1}$ to carry on the systematic exploration of the necropolis and to rescue as much as possible what was still preserved on the site. In May, the necropolis area was completely surveyed. Excavated and looted tombs were documented, their funerary furnishings listed and recorded. Human remains and other finds underwent a preliminary study and sampling, which prepare future more accurate investigations.

1 The joint team was composed as follows. MOTA-DACH: Dr. Mohammed Ghayyada, responsible for the Bethlehem district (presently carrying on a PhD on the Khalet al-Jam'a MB cemetery in Sapienza University); Dr. Wael Hamamreh, and Mr. Ayman al-Rjoob; Sapienza University: Prof. Lorenzo Nigro, director; Dr. Daria Montanari, field responsible; Mrs. Alessandra Guari, human remains and object draftsperson, Mrs. Maria

Tamburrini, surveyor and pottery draftsperson, and Federico Cappella, photographer and GPS technician. 


\section{THE NECROPOLIS}

The necropolis stretches over an area of roughly 3 hectares with a north-south extension of $320 \mathrm{~m}$ and an east-west of $200 \mathrm{~m}$ (fig. 2), exploiting the natural characteristics of the bedrock emerging in series of sloping terraces. Two main terraces with underground caves hosted two different cemeteries. On the lower southernmost terrace, the largest Intermediate Bronze Age (EB IV)-Middle Bronze I-III cemetery was located, while on the upper northernmost terrace a less densely used Iron Age cemetery was implanted. The upper cemetery was partially damaged by modern buildings, as several modern houses were erected on the top of the Hindaza hill. Only a few tombs were thus still visible. The lower cemetery, on the other hand, was cleared off for at least two thirds of its original extension. In the preserved part, at least 30 tombs were identified.

Four major areas have been distinguished on the basis of topography (fig. 3): A, B, C, and D. Area A occupies the upper northern terrace of the MB cemetery (preserved only on its western side); Area B represents the lower south-eastern quadrant (almost completely removed by bulldozer) of the same cemetery; finally, Area $\mathrm{C}$ includes the sloping southwestern quadrant of the MB cemetery. The northern cemetery falls within Area D. A rock step marks the border between the northern and southern cemeteries.

\subsection{Area A - the Middle Bronze cemetery on the north-western terrace}

Area A occupies the north-western terrace of the MB cemetery at a mean elevation of $680 \mathrm{~m}$. In this area the natural bedrock emerges at several spots with a very flat and regular surface. The geomorphology favoured tombs digging, as underground caves in the limestone were huge and numerous. A preliminary examination of the site surface allowed to identify nineteen tombs distributed in the central and western sectors. Five tombs (Tombs A1, A2, A3, A4, A6) were excavated by MOTA-DACH; two (Tomb A7, A8) were identified and protected; five tombs (Tombs A14, A15, A16, A17, A19) were found already looted and only a few materials were recovered from them. The blocked shafts of at least five more tombs (A22, A23, A24, A25, A26) were identified during the survey of May 2015. Finally, two tombs (A29 and A30) were regrettably removed by the bulldozer, and only their cut shafts were visible.

\subsubsection{Tomb A1}

Tomb A1 is a multi-chambered shaft-tomb located in the southern-central sector of Area A. Bulldozing activities damaged the tomb on its eastern side, where the modern road cut through the ancient cemetery (fig. 4). Chambers were dug exploiting communicating underground cavities and, due to the bulldozer cut, it was impossible to ascertain if some of them originally belonged to separated tombs with their own shafts. Four chambers and one shaft were identified: a main central room (Chamber 1), cut by bulldozer to the east; Chamber 2 to the north-west (communicating with Tomb A2: the passage was blocked by a stone slab); Chamber 3 to the south-west, and Chamber 4 to the north; the round shaft is opened to the north of Chamber 3. Funerary furnishing retrieved in the tombs included pottery vessels, weapons and other personal ornaments. The majority of finds were recovered in Chamber 1, while some fragments and a few complete vessels were collected from Chambers 2, 3 and 4. The chronological setting of finds is within MB IIB. 
XIX (2015) Khalet al-Jam'a. A Middle Bronze and Iron Age necropolis near Bethlehem (Palestine)

\section{Tomb A1, Chamber 1}

Human remains were unfortunately largely disturbed by collapse of the chamber roof. Three mandibles probably belonging to different individuals (a male, a female, and a child) were found in Chamber 1.

The pottery repertoire included 4 platters (Bk11/1; 6060, BK3a/1, 6253; fig. 5:1); 13 bowls with high flaring rim, pronounced shoulders and pedestal base (6009, 6063, 6064, 6065, 6066, 6083A, Bk6/1, Bk7/1, Bk14/1, Bk15/1, Bk42/1, Bk43/1, KJ.15.TA1.1/4; fig. 5:2); 2 Gublite bowls ${ }^{2}$ (6059, 6252; fig. 5:3); 2 sharply carinated bowls (6013, Bk4/1; fig. 5:4); ${ }^{3} 1$ hemispherical bowl ${ }^{4}$ (Bk3b/1; fig. 6:1); 4 dipper juglets with pinched rim (6011, 6056, Bk39/1; one Red Burnished, 6012); 5 Black Burnished piriform juglets (6054, 6055, KJ.15.TA1.1/2, KJ.15.TA1.1/3, KJ.15.TA1.1/5; fig. 6:2); 1 red-slip tankard with pedestal base (6058; fig. 6:3); twin-vases consisting of two attached juglets with stepped rim, ridge at the bottom of the neck, pronounced shoulders, triple handle, and ring base (6085; fig. 7:1); 1 jug with globular body and ring base (6251); 1 single spouted lamp (6661). Chamber 1 also yielded an alabastron (2288), one bronze toggle pin (6192), and two bronze daggers (6196, 6197; fig. 7). ${ }^{5}$

Tomb A1, Chamber 4

Only a few ceramic vases were retrieved: 1 platter with inner rounded rim and disc base (6007); 1 bowl with high flaring rim, pronounced shoulders and pedestal base (KJ.15.TA1.4/3); 2 Black Burnished piriform juglets (6014; Bk4/2).

\subsubsection{Tomb A2}

Tomb A2 is to the north of Tomb A1, along the western rocky wall of the modern street. Like Tomb A1, also A2 was sliced on its eastern side by bulldozer activities that opened its main chamber (fig. 8). It is possibly the conjunction of three different caves each having its own shaft (fig. 9). A roughly triangular rock pillar was carved out from the bedrock at the centre of the tomb between Chambers 2 and 3. Chamber 1 is the largest one (3.8 4 m). A square $(1.05 \times 1.1 \mathrm{~m})$ shaft opened on its south side; it was sealed by a rectangular slab. Another square shaft opened on the eastern side of Chamber 2, while a secondary circular one had cut through the thin bedrock wall between Chambers 2 and 3. A passage

2 Nigro 2000, 1193; Kochavi - Yadin 2002, 198; W.F. Albright stressed the metallic origin of this type of bowls (Albright 1933, 69); Amiran 1969, 90, pl. 25:1.

3 Pottery vases illustrated in fig. 5: 1, 6253, outer slip 5YR 8/2 pinkish white, inner slip 5YR 8/2 pinkish white, inner colour 10YR 6/4 red, fabric colour 10YR 6/4 red, comparable with Kenyon 1965, fig. 222:2; 2, 6063 , outer slip 10YR 8/2 white, comparable with Kenyon 1965, fig. 113:2; 3, 6059, fabric colour 10YR 6/4 pale red, outer colour 10YR 6/4 pale red, inner colour 10YR 6/4 pale red; 4 , Bk4/1, outer slip 10YR 8/3 very pale brown, fabric colour 2.5YR 6/4 light reddish brown, inner colour 2.5YR 6/4 light reddish brown, comparable with Kenyon 1965, fig. 157:6.

4 Beck 2000, 174

5 Pottery vases illustrated in fig. 6: 1, Bk3b/1, fabric colour 5YR 4/6 reddish yellow, outer colour 5YR 4/6 reddish yellow, inner colour 2.5YR 6/6 light red; 2, 6055, outer burnish 5YR 7/1 light gray; 3, 6058, fabric colour 10R 6/3 pale red, outer colour 10R 6/3 pale red, inner colour 10R 6/3 pale red. Twin-vases illustrated in fig. 7: 1, 6085, outer slip 2.5YR 6/6 light red, fabric colour 5YR 6/8 light red. Toggle pin 6192 can find comparison with Tomb B3 at Jericho (Kenyon 1960, fig. 165:1). Two fragmentary cooking pots and other pottery sherds dating to Iron Age II were found in the area of Chamber 1 of Tomb A1 suggesting a later reuse of this burial complex. 
connecting Chamber 2 and nearby Tomb A1 was found blocked. Both Chambers 2 and 3 had a raised niche inside (presumably for hosting a lamp and dug in the EB IV?). Pick marks were visible on the chambers rock cut ceilings and in the shafts.

More than one hundred complete vessels were found in Tomb A2 distributed in the three chambers, as well as several bronze and stone objects. An Intermediate Bronze Age/Early Bronze IV four lips lamp (6039; fig. 16:1) and the fragment of a tray wall (Bk16/1) found in Chamber 3 may indicate that the tomb was originally used in this period.

\section{Tomb A2, Chamber 1}

Sparse human bones ${ }^{6}$ were found in this chamber referable to different individuals. Some animal bones (ovis vel capra) were probably connected to food offerings.

This chamber yielded 62 almost complete vessels: 1 single spouted lamp (6001); 5 platters (6006, 6049, 6079, 6081, 6170); a three-footed deep bowl with triangular rim (6067; fig. 10:1); 2 White Slip Gublite bowls with disc base (6047, 6048); a Gublite like bowl with pedestal and triple handle (6077; fig. 11);15 White Slip bowls with flaring rim, pronounced shoulders and pedestal base (2283, 2284, 2285, 6008, 6017, 6026, 6052, 6083B, 6167, Bk9/1, Bk51/1, Bk55/1, Bk75/1, Bk82/1, KJ.15.TA2.1/3; fig. 10:2); 2 small jars (6082, 6027 carinated); 13 dipper juglets with pinched rim, loop handle and pointed base (2286, 6021, 6022, 6023, 6038, 6043, 6045, 6051, 6142, 6143, 6169, 6237, Bk83/1); 8 piriform juglets (6010, 6024, 6036, 6037, 6041, 6050, Bk56/1, KJ.15.TA2.1/2; fig. 10:3); 4 juglets with carinated shoulders (6025, 6042, 6044, 6168); a Tell el-Yahudiyeh cylindrical juglet (6238); a cylindrical juglet (6046); 1 ovoid jug (6053); 7 ovoid jars with two or four handles (6087, 6088, 6232, 6234, 6235, 6250, KJ.15.TA2.1/1). ${ }^{7}$

Chamber 1 also gave back a small group of bronzes (fig. 12): three daggers, one socketed axe, and a toggle pin. Dagger $\mathrm{n}^{\circ} 6187$ is $21.1 \mathrm{~cm}$ long; it has a straight tang and two preserved rivets, flattened lozenge-shaped cross-section. It possibly belongs to a renowned early Mycenean type. Dagger $n^{\circ} 6188$ exhibits a peduncolar tang to be inserted into a wooden handle ending with round-shaped fine limestone pommel with domed crosssection; its blade has hexagonal cross-section. ${ }^{8}$ Dagger ${ }^{\circ}$ 6189, $14.5 \mathrm{~cm}$ long, shows a thinner flat cross-section, one central rivet and a rounded point.

The socketed axe (6186) has two ribs along the edge, the shaft-hole is decorated by two ridges and one hook, the blade has a lenticular cross-section. ${ }^{9}$ The axe was found together with dagger $n^{\circ} 6188$, both deposited upon a stone slab at the centre of the chamber.

6 Fragments of crania, teeth, humerus, clavicles, ulnas and phalanges are reported.

7 Pottery vases illustrated in fig. 10: 1, 6067, fabric colour 2.5YR 6/4 light reddish brown, outer colour 2.5YR 6/4 light reddish brown, inner colour 2.5YR 6/4 light reddish brown, comparable with Kenyon 1960, fig. 160:4 (without hooked handles); 2, 6026, outer slip 5YR 7/6 reddish yellow, fabric colour 5YR 7/4 pink, inner colour 5YR 7/4 pink, comparable with Kenyon 1965, fig. 144:3; 3, 6021, outer slip 10YR 8/2 white, fabric colour 10YR 8/4 very pale brown, inner colour 10YR 8/3 very pale brown. The bowl 6077 illustrated in fig. 11: fabric colour 10YR 5/6 red, outer colour 10YR 5/6 red, inner colour 10YR 5/6 red. The jar KJ.15.TA2.1/1 is on display in the Bethlehem Museum (see Nigro 2015, fig. 3).

8 Dagger 6188 finds a comparison with Tomb D9 at Jericho (Kenyon 1965, fig. 111:11), and with Grave 3 at Tell ed-Dab‘a (Philip 2006, 50, fig. 17:4).

9 The axe 6186 can be compared with the one recovered from Tomb 9 at Jericho by J. Garstang (1932, pl XXVII:3; Philip 2006, fig. 9:1). It can be included in narrow, elongated socket axes - Type II, variant 2 of Miron’s typology (Miron 1992, 71). 
XIX (2015) Khalet al-Jam'a. A Middle Bronze and Iron Age necropolis near Bethlehem (Palestine)

The bronze toggle pin (6183) ${ }^{10}$ is $13.9 \mathrm{~cm}$ belonged to the incised type. It was possibly associated with a carnelian bead (6175).

Two so-called 'Hyksos' scarabs $(4368,4369)$ complete the funerary set of Chamber 1 (fig. 13). ${ }^{11}$

Tomb A2, Chamber 2

Chamber 2 was probably an autonomous tomb at the beginning, with a square (side 0.75 $\mathrm{m})$ shaft to the east. It is $3.5 \times 3 \mathrm{~m}$ wide. Human remains in this tomb were not preserved. Its ceramic inventory includes 3 bowls with straight walls and inverted rim (6069, 6239; 6068 radially burnished; fig. 14:1); 1 bowl with slight carination (6076); 1 hemispherical bowl $^{12}$ (6240) (fig. 14:2); 4 White Slip bowls with flaring rim, pronounced shoulders and pedestal base (6074, 6075, 6078, 6244); 4 Dark Faced Burnished juglets (6035, 6070, 6071, 6072); 1 dipper jug (6242; fig. 14:3) and 1 dipper juglet (6073). ${ }^{13}$

Two bronze toggle pins $(6176,6182)^{14}$ and a needle $(6184)$ were possibly associate to female individuals buried in this chamber, as well as the bottom of a fragmentary calcite alabastron (6185).

\section{Tomb A2, Chamber 3}

Chamber 3 has a round plan and a dome roof. It is $2.8 \mathrm{~m}$ wide, with a raised niche on the north-eastern side (fig. 15). A circular shaft (3), located in between Chambers 2 and 3, might have been the original access to Chamber 3 .

Chamber 3 gave back 23 pottery vessels and 4 bronzes. The ceramic repertoire is represented by: 1 single spouted lamp (6033); 5 platters (6018, 6019, 6020, 6031, 6241); 2 Gublite bowls (6002 with incised cross on the base, 6029; fig. 16:2); a sharply carinated bowl (6034); 5 White Slip bowls with flaring rim, pronounced shoulders and pedestal base (6003, 6032 with incised cross on the base, Bk5a/1, Bk5b/1, Bk5c/1; fig. 16:3); 2 dipper juglets (6005, 6243; fig. 17:1); a Black Burnished piriform juglet (6030); 2 fragmentary juglets (Bk16/3, Bk16/4); 2 jars (6233, Bk16/2; fig. 17:2). ${ }^{15}$

Two bronze toggle pins $(6177,6181)^{16}$ and two bronze needles $(6178,6179)$ were included into the (female?) funerary equipment of Chamber 3.

10 Toggle pin 6183 can find comparison at Jericho in Tomb J1 (Kenyon 1960, fig. 177:12).

11 Scarab 4369 is incised with concentric circles (Ben-Tor 2004, 34, fig. 5) and it can be compared with one specimen from Tomb P17 at Jericho (Kirkbride 1965, fig. 289:2).

12 Cohen 2002, 114-115, fig. 1:2.

13 Pottery vases illustrated in fig. 14: 1, 6068, inner+outer burnish 2.5YR 5/6 red, fabric colour 2.5YR 5/6 red, comparable with Cohen 2002, fig. 5:2; 2, 6240, fabric colour 5YR 6/6 reddish yellow, outer colour 5YR 7/6 reddish yellow, inner colour 5YR 6/6 reddish yellow; 3, 6242, fabric colour 5YR 7/6 reddish yellow, outer colour 5YR 7/3 pink, inner colour 5YR 7/6 reddish yellow.

14 The plain shaft toggle pins recovered from the Khalet al-Jam'a necropolis recall Klein's types I.31a-b (Klein 1992, pl. 61:1), and I.6A1b (Klein 1992, pl. 80:4-6).

15 Pottery vases illustrated in fig. 16: 1, 6039, fabric colour 2.5YR 6/2 pale red, outer colour 2.5YR 6/6 light red, inner colour 2.5YR 6/6 light red; 2, 6002, fabric colour 2.5YR 6/4 light reddish brown, outer colour 2.5YR 6/4 light reddish brown, inner colour 2.5YR 6/4 light reddish brown; 3, 6003, outer slip 2.5YR 8/2 white. Pottery vases illustrated in fig. 17: 1, 6243, outer slip 5 YR 8/3 pink; 2, 6233, combed and incised decoration, fabric colour 5 YR 7/3 pink, outer colour 5 YR 7/6 reddish yellow, inner colour 5 YR 7/6 reddish yellow.

16 Toggle pins can find comparisons at Jericho, respectively in Tombs H18 and B51 (Kenyon 1960, fig. 207:19; 1965, fig. 174:2) 


\subsubsection{Tomb A3}

Tomb A3 is located north-west of Tomb A2 and to the west of Tomb A4. Bulldozer cut through the shaft leaving the main oval chamber visible from the road (fig. 18). The shaft was circular (around $0.9 \mathrm{~m}$ of diameter). The shape of the domed chamber was regular. Some fragmentary animal bones were collected from this tomb.

\subsubsection{Tomb A4}

Tomb A4 is located north of Tomb A2. Also this tomb was damaged by bulldozer activity; the eastern part of its shaft was cut away (fig. 19). The shaft was square and opened into a roughly circular chamber. Some fragmentary human bones (a cranium) were collected from this tomb.

\subsubsection{Tomb A6}

Tomb A6, located roughly in the middle of Area A, had been badly damaged by modern building activities and belonged to a different architectural type in respect of the others. It had a short dromos followed by a small rectangular ( 2 x $1.2 \mathrm{~m})$ chamber. As no finds were collected in it, its dating remains uncertain.

\subsubsection{Tomb A7}

Tomb A7 is located in the south-western sector of Area A. It was discovered and only partially explored during survey activities of Spring 2015. It has an irregular oval shaft (fig. 20), and a huge underground chamber subdivided into small partitions by walls made of regular stones (fig. 21). Due to roof collapses and possible looting attempts, the chamber was found filled up with limestone chops and erosion soil. It concealed Iron Age II ceramic material, ${ }^{17}$ possibly belonging to funerary furnishings (fig. 22). ${ }^{18}$

The retrieval of a basalt grinding stone, two flint globular pestles, and a clay animal figurine, ${ }^{19}$ suggests that the cave might have been reused.

\subsection{Area B - the Middle Bronze cemetery}

Area B is in the south-eastern sector of the necropolis, and it is delimited by the road of the factory area to the west and by the modern road climbing towards the modern water tower to the east. It was almost completely removed by building activities (including massive concrete pouring). As tombs were identified all around the newly built area, this suggests that at least two dozens of tombs were completely cleared off. Three tombs were surveyed at the north-west corner of the Area (B9, B10, B11).

177 single spouted lamps (KJ.15.TA7/1, 2, 5, 7, 8, 9, 10); twin-bowls (KJ.15.TA7/23; fig. 21:1); 7 Red Slip kraters (KJ.15.TA7/3, 11, 12, 15, 17, 24, 26; fig. 21:2); 3 jugs (KJ.15.TA7/4, 6, 21); 7 jars (KJ.15.TA7/13, 14, 16, 20, 22, 25, 27); 2 pots (KJ.15.TA7/18, 19).

18 Pottery vases illustrated in fig. 22: 1, KJ.15.TA7/23, fabric colour 5YR 7/1 light gray, outer colour 2.5 YR 6/6 light red, inner colour 2.5 YR 6/6 light red; 2, KJ.15.TA7/12, inner+outer slip and burnish 2.5 YR 5/8 red, fabric colour 5 YR 7/1 light gray.

19 The figurine is a solid handmade quadruped (Holland 1977, 123, type G; 1995, 167-168, type D), possibly the hindquarters of horse, with preserved tail curving downwards under the belly of the animal, between the broken legs (Yezerski - Geva 2003, pl. 3:6: F178). 
XIX (2015) Khalet al-Jam'a. A Middle Bronze and Iron Age necropolis near Bethlehem (Palestine)

\subsubsection{Tomb B9}

The eastern half of Tomb B9 was completely removed for building the foundation of a factory, so that it was visible in section. It originally consisted of two chambers, with a square shaft located to the south-west in Chamber 1 . Chamber 1 had a round irregular shape almost $4 \mathrm{~m}$ long on the north-south axis, while Chamber 2 was smaller.

Tomb B9, Chamber 1

A few human remains were preserved: crania fragments, ribs, sterni, scapulae, vertebrae, phalanges, and metatarsus referable to two individuals.

Some pottery vessels probably were part of the tomb furnishings: a Gray Burnished piriform juglet (6057), and a Canaanite jar with grooved rim and two combed bands on the shoulders (6236; fig. 23). ${ }^{20}$

Tomb B9, Chamber 2

Vessels recovered from the bulldozed Chamber 2 are a few: a four spouted lamp (KJ.15.TB1.2/1), and a jar with decorated neck (KJ.15.TB1.2/2, fig. 24) ${ }^{21}$ to be connected with an Intermediate Bronze Age/EB IV internment; a dipper juglet (6062); and a jar (6247) referable to a MB II burial.

\subsubsection{Tomb B10}

Tomb B10 was located a few meters to the north of Tomb B9 and had originally one chamber and one circular shaft to the south. It was excavated by the MOTA-DACH before its complete removal. Remains of a male individual were found in Chamber $2{ }^{22}$

The funerary equipment consisted of 2 four spouted lamps (6080, 6174), and 2 jars with globular body and large flat base $(6157,6173 \text {; fig. } 25)^{23}$ dating back to the Intermediate Bronze Age/Early Bronze IVB. ${ }^{24}$

\subsubsection{Tomb B11}

Tomb B11 is located to north-east of Tomb B9, near to the northern limit or Area B. It was entered through a round shaft and consisted of a round domed chamber (fig. 26). The tomb was cut along its southern wall by bulldozer. Into the chamber a storage jar with four handles (6249; fig. 27), ${ }^{25}$ and a bronze needle (6193) were retrieved after possible looting of the rest of the assemblage.

20 Canaanite jar 6236 illustrated in fig. 23: outer colour 5YR 7/4 pink; a comparison for the rim is in Franken 2005, fig. 3.2.84.

21 Jar KJ.15.TB1.2/2 illustrated in fig. 24: fabric colour 2.5YR N5 gray, outer colour 2.5YR 6/4 light reddish brown, inner colour 2.5YR 6/4 light reddish brown.

22 Cranium, mandible and teeth.

23 Jar 6173 illustrated in fig. 25: fabric colour 5 YR 7/4 pink, outer colour 5 YR 7/4 pink, inner colour 5 YR 7/4 pink, comparable with Tomb 30 at el-Jib/Gibeon (Pritchard 1963, fig. 33:38).

24 Jar 6173 recalls Kenyon's type J (Kenyon 1965, 42, fig. 18:27), with rim wheel-made and body regularly hand-made. Nigro 2003a, 134; D’Andrea 2012, $22-23$.

25 Jar 6249 illustrated in fig. 27: fabric colour 5 YR 7/4 pink, outer colour 5 YR 8/3 pink, inner colour 5 YR 8/3 pink. 


\subsection{Area $C$ - the Intermediate Bronze Age/Early Bronze IV cemetery}

Area $\mathrm{C}$ is the south-western sector of the necropolis. In this area the MOTA-DACH dug two tombs (Tomb C5 and Tomb C12) during rescue excavations. Unfortunately, two tombs (C18 and C20) were looted before DACH intervention.

Other three Tombs (C26, C27, C28) were identified in the north-central zone of the area during the 2015 survey, presumably belonging to the MB cemetery.

\subsubsection{Tomb C5}

Tomb C5 is along the western border of the modern road. It has a square shaft, located to south-east of a single round chamber. Some pottery sherds and one triangular flint blade (6194) were retrieved inside it pointing to an Intermediate Bronze Age/Early Bronze IV dating.

\subsubsection{Tomb C12}

Tomb C12 is a shaft tomb provided with a round domed chamber, and a squared shaft to the south. One male almost complete inhumation was find inside this tomb (fig. 28).

A four spouted lamp (6040; fig. 29) ${ }^{26}$ represents the only funerary equipment collected in Tomb C12, indicating that the tomb belonged to the original Intermediate Bronze Age/Early Bronze IV cemetery.

\subsection{Area $D$}

The northernmost terrace of the necropolis was named Area D. This area could represent a northern later expansion of the necropolis. Nowadays, it is encompassed in private estates and houses. In the western half of the area, during some construction works in a private property of Barmil's family, a tomb was discovered due to a bulldozer cut.

\subsubsection{Barmils' Tomb (Tomb D13)}

The tomb has a roughly round main chamber, which was cut by the bulldozer on its southern side, and a round shaft to the west (fig. 30). The shaft it is still partly unexcavated. A second smaller chamber, a kind of repository, opens on the northern side of the main chamber. It apparently was used for a relatively long period and hosted several inhumations. Finds include typical Iron Age II shapes, such as 7 Black Ware juglets (fig. 31:1), 4 one-spouted lamps (fig. 31:2), ${ }^{27}$ a Red Slip painted neck ridge jug (6128), a strainer-spouted jug (6129; fig. 32:1), a typical chalice/incense burner with high foot (6133; fig. 32:2), ${ }^{28}$ and some personal ornaments. ${ }^{29}$ Tomb fittings from Tomb D13 cover a time span ranging from Iron IB to Iron IIC.

26 Lamp 6040 illustrated in fig 29: fabric colour 10YR 5/6 red, outer colour 2.5YR 6/6 light red, inner colour 2.5YR 6/6 light red, comparable with Tomb G27 (Kenyon 1960, fig. 103:6).

27 These lamps find a comparison with an item recovered from Tomb WH.I at Jebel el-Dhaweiyat (Tushingam 1965, fig. 259:2).

28 Pottery vases illustrated in fig. 31: 1, 6129, outer colour 2.5YR 6/6 light red, inner colour 2.5YR 6/6 light red; 2, 6133, fabric colour 7.5YR 7/4 pink, outer colour 7.5YR 7/6 reddish yellow, inner colour 7.5YR 7/6 reddish yellow. 
XIX (2015) Khalet al-Jam'a. A Middle Bronze and Iron Age necropolis near Bethlehem (Palestine)

\section{BUILT UP INSTALLATIONS IN THE NECROPOLIS AREA}

Some built up installations were identified in the area of the necropolis, showing the long lasting occupation of the south-eastern flank of the Hindaza hill (fig. 33).

A rock-cut wine press was uncovered in Area A (figs. 34-35), probably dating to the Byzantine Period. It consists of a large pressing vat, $2.5 \times 2.7 \mathrm{~m}$, carved out in the bedrock and connected by means of short channels with two other smaller square basins. The three rock-cut vats were plastered with a pinkish hydraulic revetment $1.2 \mathrm{~cm}$ thick. Southeast of these two square basins, there is a couple of round installations, also connected with wine production.

In Area A, two circular stone built lime kilns, also dating to the Byzantine Period were found north of Tomb A7. Moreover, roughly at the centre of the lower terrace and in proximity of the same tomb, the limestone boulders foundations of an Iron Age tower was uncovered (fig. 36). Such a structure was adjoined to an east-west enclosure wall with a width of $1 \mathrm{~m}$. Tomb A7 extended northwards up to the bedrock platform upon which the tower was erected.

\section{CONCLUSIONS: THE NECROPOLIS OF KHALET AL-JAM’A, A PRELIMINARY OVERVIEW}

The necropolis of Khalet al-Jam'a is mainly characterized by shaft-tombs with single or multiple rock-cut chambers, realized by regularizing underground existing cavities. In spite of the lost of a large part of it, the overall number of tombs can be reconstructed over one hundred. ${ }^{30}$ Tombs shafts generally are round or square and chambers are roughly circular in plan and domed, often provided with niches. Due to the temporally extended utilization of the necropolis, tombs were crowded and often chambers were connected as to create larger familiar hypogea. On the upper surface of bedrock, shafts' mouths are sometimes flanked by cup-marks, indicating that funerary rites occurred outside tombs after their closing. Tombs basically belong to three periods: Intermediate Bronze/Early Bronze Age IV, Middle Bronze and Iron Age. In some cases Intermediate Bronze Age/Early Bronze IV tombs were re-used in the Middle Bronze Age.

Both in IB/EB IV and in MB I-III inhumations were in primary articulated displacement and they were accompanied by ordinary funerary sets, consisting of pottery vessels, food offerings, personal ornaments and in certain cases of bronze weapons and signet rings with scarabs. ${ }^{31}$

The ceramic inventory shows a wide variety of shapes, from platters to different types of carinated bowls, ${ }^{32}$ jugs, juglets and jars, as well as several specialised wares, such as Red Burnished Ware, ${ }^{33}$ Tell el-Yahudiyeh, Black or Dark Faced Burnished Ware, ${ }^{34}$ the

29 They include two bronze bracelets, some beads made of carnelian and vitreous materials, a decorated bone disc, and a frît eye-udjat; they can be compared with those from Tomb WH.I at Jebel el-Dhaweiyat (Tushingam 1965, 491-513, figs. 260-261).

30 The number of tombs is actually a relative figure in respect of the groups using it, being them nomadic or seminomadic pastoralists in EB IV, and the inhabitants of the town of Bethlehem in MB and IA.

31 Nigro 2009, 367, 371

32 Beck 1985, 194.

33 Beck 2000, 195.

34 Nigro 2003b, 351-353. 
latter basically employed for small juglets possibly serving as containers of ointments or drugs. 35

Bronze daggers, socketed axes, toggle pins and needles also fall well into the regular equipment of individuals (respectively male and female) of the Middle Bronze Age.

The presence of an Iron Age cemetery in Area D is another important information obtained thanks to salvage excavations in Khalet al-Jam'a, as well as the discovery of a single major Iron Age tomb (A7) in the nearby of an Iron Age tower (see above $\S 3$.) in the central sector of Area A.

Further systematic investigation at the site, when possible, will protect an important piece of the archaeology of Palestine and will provide a more detailed information on the ancient communities living in Bethlehem in the $2^{\text {nd }}$ and $1^{\text {st }}$ millennium BC.

\section{REFERENCES}

AlBRight, W.F.

1933 The Excavation of Tell Beit Mirsim, the Bronze Age Pottery of the Fourth Campaign: Annual of American School of Oriental Research 13 (1933), pp. 55-127.

AMIRAN, R.

1969 Ancient Pottery of the Holy Land, From the Prehistoric to the Persian Period, Jerusalem 1969.

BECK, $\mathrm{P}$.

1985 The Middle Bronze Age IIA Pottery from Aphek, 1972-1984: First Summary: Tel Aviv 12 (1985), pp. 181-203.

2000 Chapter 10. Area A: Middle Bronze IIA Pottery: M. KochAVI - P. BECK. - E. YAdin (eds.), Aphek-Antipatris I. Excavation of Areas A and B. The 1972-1976 Seasons (Emery and Claire Yass Publications in Archaeology. Tel Aviv University Monograph Series 19), Tel Aviv 2000, pp. 173-238.

BEN-TOR, D

2004 Second Intermediate Period Scarabs from Egypt and Palestine: Historical and Chronological Implications: M. BIETAK - E. CZERNY (eds.), Scarabs of the Second Millennium BC from Egypt, Nubia, Crete and the Levant: Chronological and Historical Implications. Papers of a Symposium, Vienna, $10^{\text {th }}-13^{\text {th }}$ of January 2002 (Österreichische Akademie der Wissenschaften. Denkschriften der Gesamt-akademie, Band XXV), Wien 2004, pp. 27-41.

COHEN, S.L.

2002 Middle Bronze Age IIA Ceramic Typology and Settlement in the Southern Levant: M. BIETAK (ed.), The Middle Bronze Age in the Levant. Proceedings of an International Conference on MB IIA Ceramic Material. Vienna, 24 $24^{\text {th }}-26^{\text {th }}$ of January 2001 (Contributions to the Chronology of the Eastern Mediterranean Volume 3. Österreichische Akademie der Wissenschaften. Denkschriften der Gesamt-akademie, Band XXVI), Wien 2002, 113-131.

D'ANDREA, M.

2012 The Early Bronze IV Period in South-Central Transjordan: Reconsidering Chronology through Ceramic Technology: Levant 44 (2012), pp. 17-50.

35 Nigro 2000, 1194. 
XIX (2015) Khalet al-Jam’a. A Middle Bronze and Iron Age necropolis near Bethlehem (Palestine)

FRANKEN, H.J.

2005 A History of Potters and Pottery in Ancient Jerusalem. Excavations by K.M. Kenyon in GARSTANG, J. Jerusalem 1961-1967, London 2005.

1932 City and Necropolis: Liverpool Annals of Archaeology and Anthropology XIX (1932), pp. 35-54.

HOLLAND, T.A.

1977 A study of Palestinian Iron Age Baked Clay Figurines, with special reference to Jerusalem: Cave 1: Levant 9 (1977), pp. 121-155.

1995 A study of Palestinian Iron Age Baked Clay Figurines, with Special Reference to Jerusalem: Cave 1: I. ESHEL - K. PRAG (eds.), Excavations by K.M. Kenyon in Jerusalem 1961-1967. Volume IV. The Iron Age Cave Deposits on the South-east Hill and Isolated Burials and Cemeteries Elsewhere (British Academy Monographs in Archaeology 6), Jerusalem 1995, pp. 159-189.

KENYON, K.M.

1960 Excavations at Jericho. Volume One. The Tombs excavated in 1952-1954, London 1960.

1965 Excavations at Jericho. Volume Two. The Tombs Excavated in 1955-1958, London 1965.

KIRKBRIDE, D.

1965 Appendix E. Scarabs: K.M. KenYON, Excavations at Jericho. Volume Two. The Tombs Excavated in 1955-1958, London 1965, pp. 580-655.

KLEIN, H.

1992 Untersuchung zur Typologie bronzezeitlicher Nadeln in Mesopotamien und Syrien (Schriften zur Vorderasiatischen Archäologie), Saarbrücken 1992.

Kochavi, M. - YADIN, E.

2002 Typological Analysis of the MB IIA Pottery from Aphek according to its Stratigraphic Provenance: M. BIETAK (ed.), The Middle Bronze Age in the Levant. Proceedings of an International Conference on MB IIA Ceramic Material. Vienna, 24 ${ }^{\text {th }}-26^{\text {th }}$ of January 2001 (Contributions to the Chronology of the Eastern Mediterranean Volume 3. Österreichische Akademie der Wissenschaften. Denkschriften der Gesamt-akademie, Band XXVI), Wien 2002, pp. 189-225.

Miron, E.

$1992 \quad$ Axes and Adzes from Canaan (Prähistorische Bronzefunde 9), Stuttgart 1992.

NigRo, L.

2000 Coordinating the MB I pottery horizon of Syria and Palestine: P. MAtThiAe - A. ENEA - L. PEYRONEL - F. PinNoCK (eds.), Proceedings of the First International Congress on the Archaeology of the Ancient Near East. Rome, May 18 ${ }^{\text {th }}-23^{r d}$, Rome 2000, pp. 1187-1210.

2003a Tell es-Sultan in the Early Bronze Age IV (2300-2000 BC). Settlement VS Necropolis - A Stratigraphic Periodization: Contributi e Materiali di Archeologia Orientale 9 (2003), pp. 121-158.

2003b The Smith and the King of Ebla. Tell el Yahudiyeh Ware, Metallic Wares and the Ceramic Chronology of Middle Bronze Syria: M. BIETAK (ed.), The Synchronisation of Civilisations in the Eastern Mediterranean in the Second Millennium B.C. Proceedings of the SCIEM 2000 - EuroConference. Haindorf, $2^{\text {nd }}$ of May - $7^{\text {th }}$ of May 2001 (Österreichische Akademie der Wissenschaften. Denkschriften der Gesamt-akademie Band XXIX), Wien 2003, pp. 345-363. 
2009 The Built Tombs on the Spring Hill and The Palace of the Lords of Jericho ('dmr Rha) in the Middle Bronze Age: J.D. SCHLOEN (ed.), Exploring the longue durée. Essays in Honor of Lawrence E. Stager, Winona Lake 2009, pp. 361-376.

2015 Bethlehem in the Bronze and Iron Age. A Summary in the light of recent discoveries by The Palestinian MOTA-DACH: Vicino Oriente XIX (2015), pp. 1-24.

PHILIP, G.

2006 Tell el-Dab‘a XV. Metalwork and Metalworking Evidence of the Late Middle Kingdom and the Second Intermediate Period (Österreichische Akademie der Wissenschaften. Denkschriften der Gesamt-akademie, Band XXXVI), Wien 2006.

PRITCHARD, J.B.

1963 The Bronze Age Cemetery at Gibeon (Museum Monographs), Philadelphia 1963.

TushingAm, A.D.

1965 Tombs of the Early Iron Age: K.M. KENYon, Excavations at Jericho, Volume Two. The Tombs Excavated in 1955-1958, London 1965, pp. 479-515.

YEZERSKI, I. - GEVA, H.

2003 Iron Age II Clay Figurines: H. Geva (ed.), Jewish Quarter Excavations in the Old City of Jerusalem Conducted by Nahman Avigad, 1969-1982. Volume II: The Finds from Areas $A, W$ and $X$-2. Final Report (Israel Exploration Society), Jerusalem 2003, pp. 63-84. 
XIX (2015) Khalet al-Jam’a. A Middle Bronze and Iron Age necropolis near Bethlehem (Palestine)

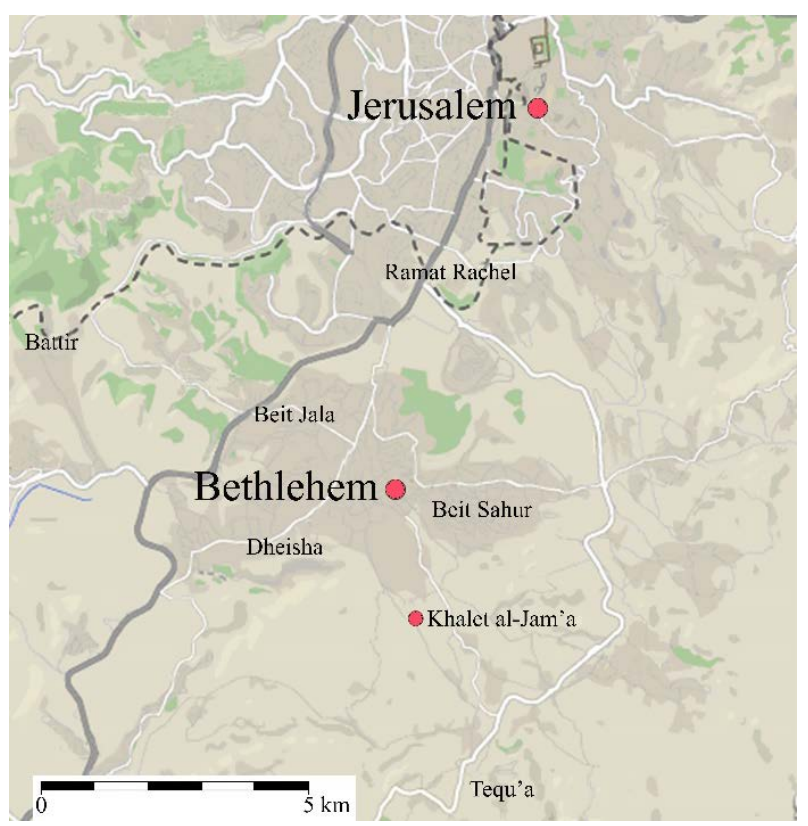

Fig. 1 - Map of Bethlehem with the necropolis of Khalet al-Jam'a.

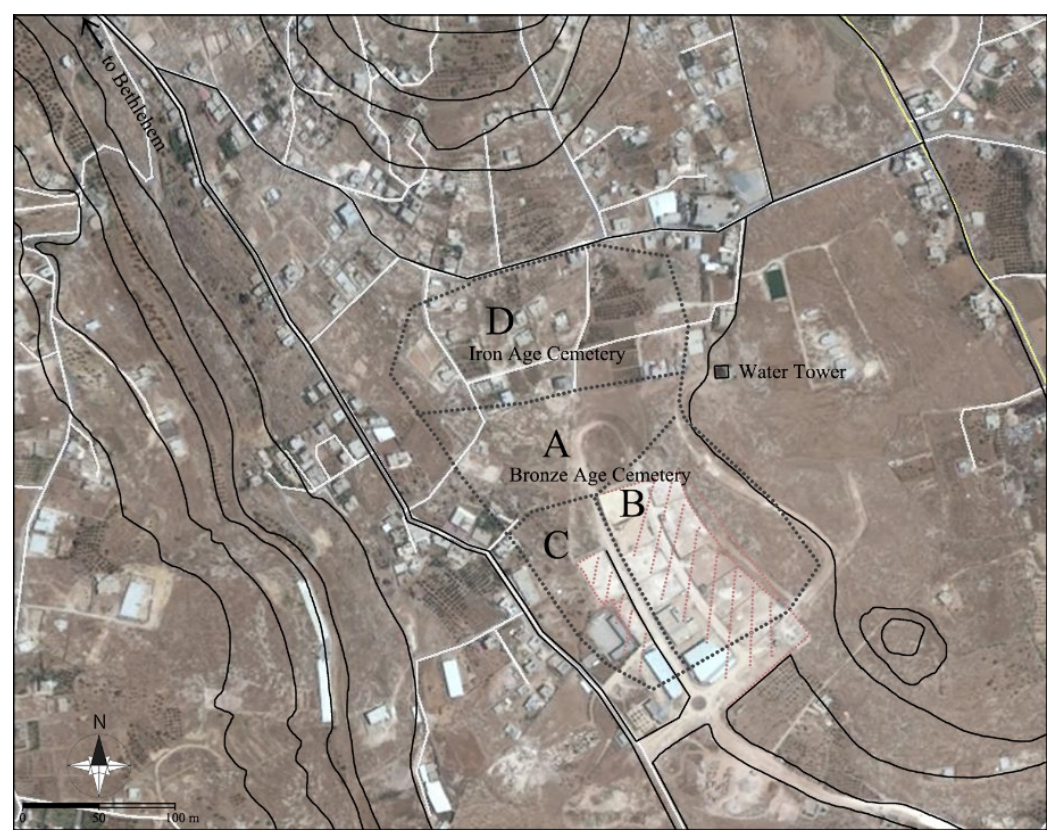

Fig. 2 - Sketch map of Khalet al-Jam’a necropolis overlying a satellite photo. 


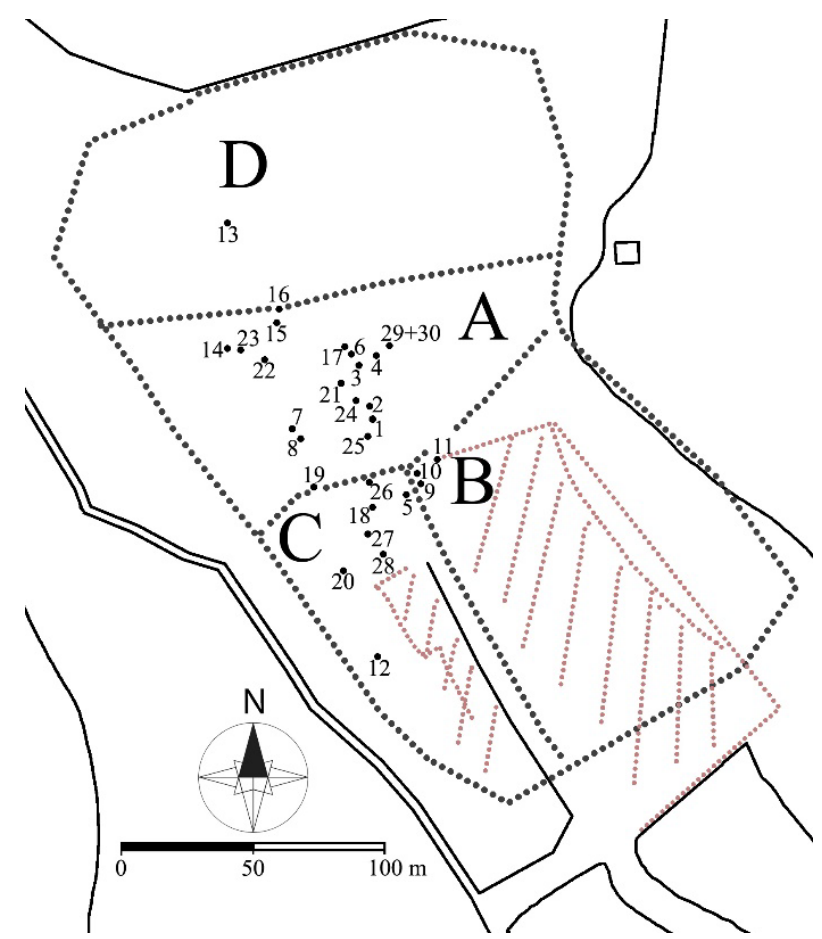

Fig. 3 - Plan of the necropolis with subdivision in areas and tombs.

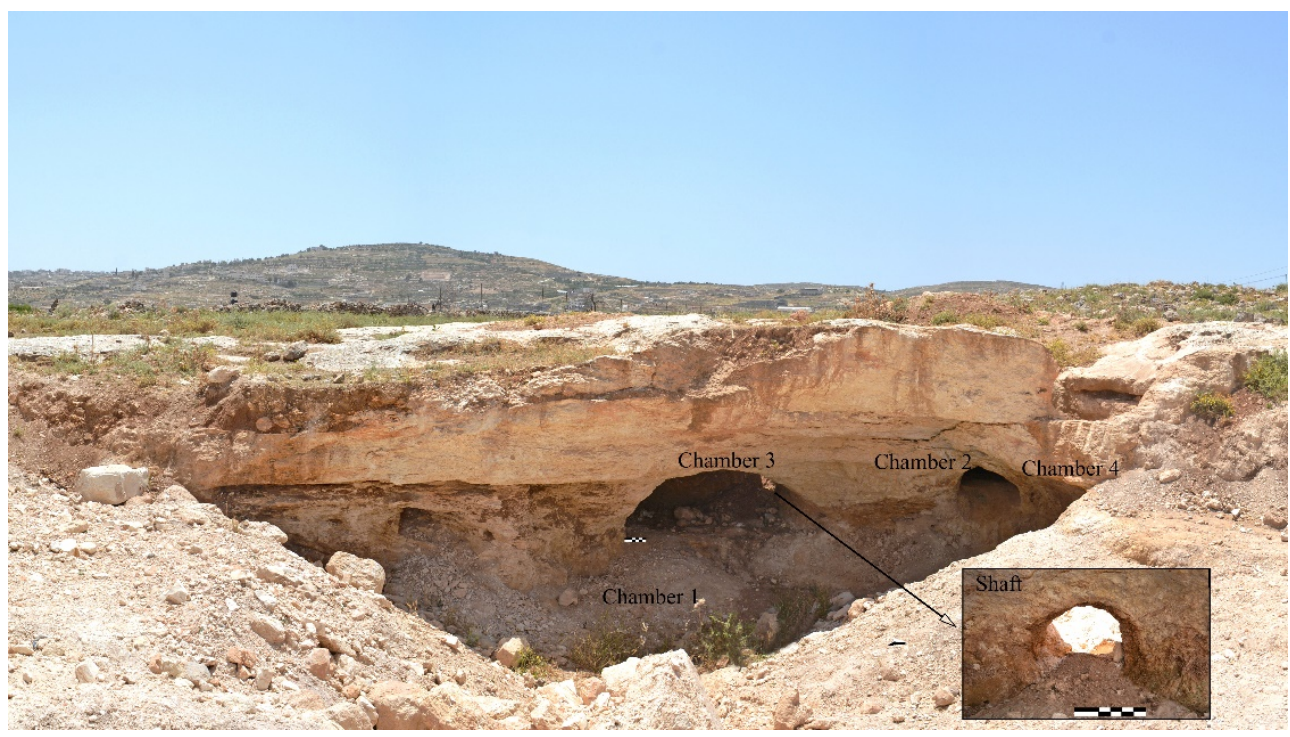

Fig. 4 - Tomb A1 cut by the bulldozer; from the north-east. 
XIX (2015) Khalet al-Jam’a. A Middle Bronze and Iron Age necropolis near Bethlehem (Palestine)
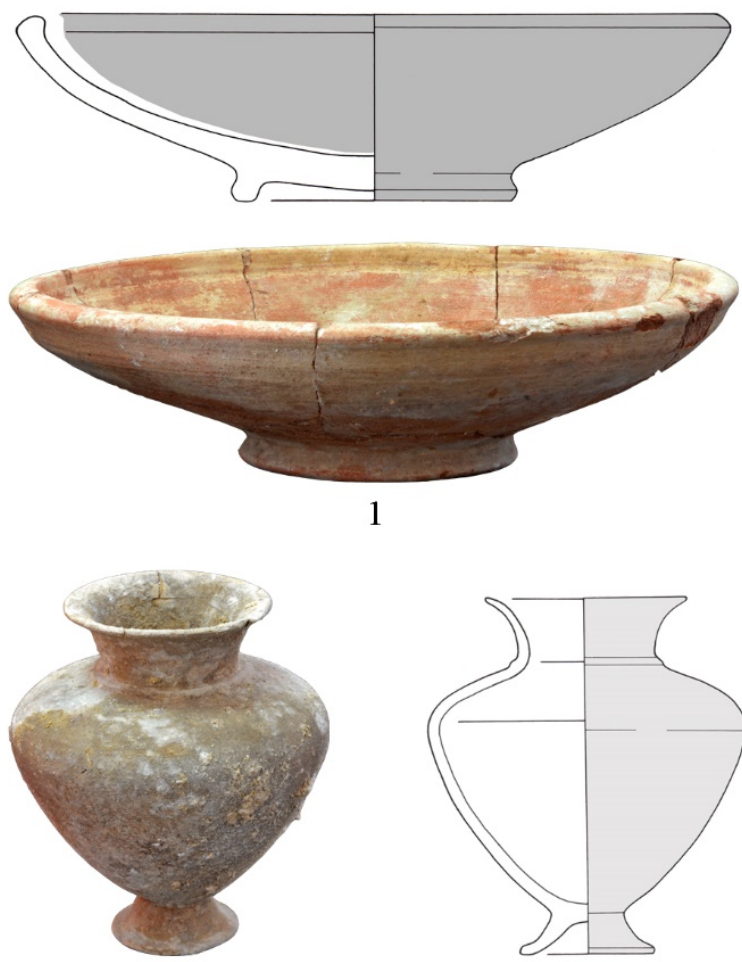

2
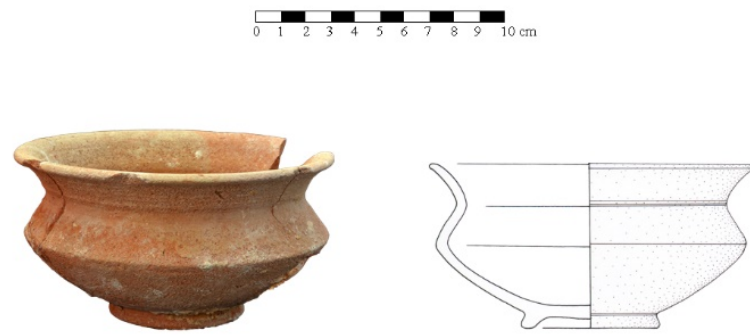

3
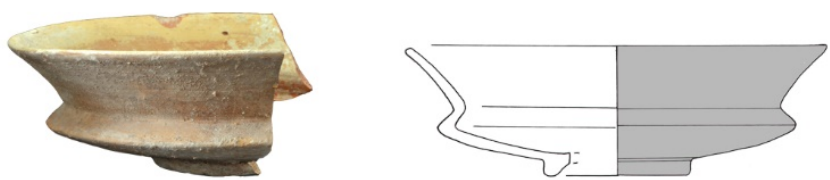

4

Fig. 5 - Middle Bronze pottery from Chamber 1 of Tomb A1 (1:4). 

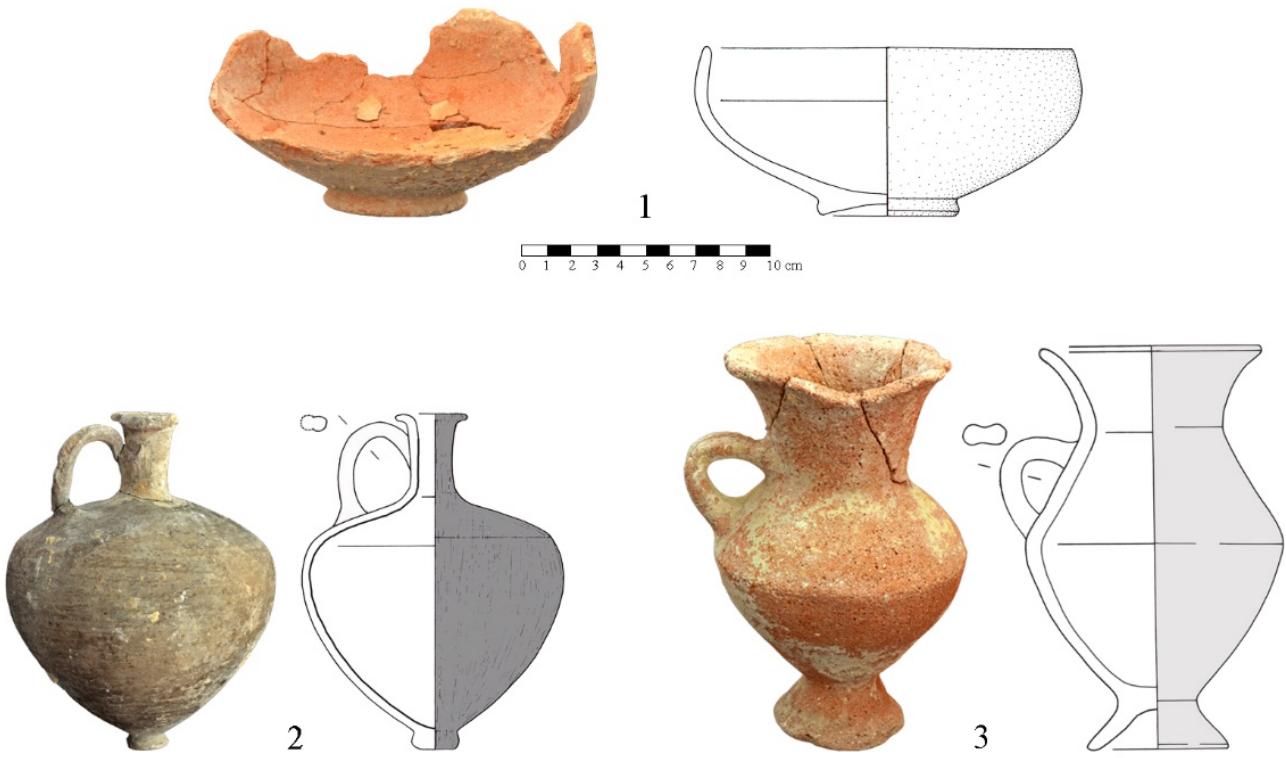

Fig. 6 - Middle Bronze pottery from Chamber 1 of Tomb A1 (1:4).
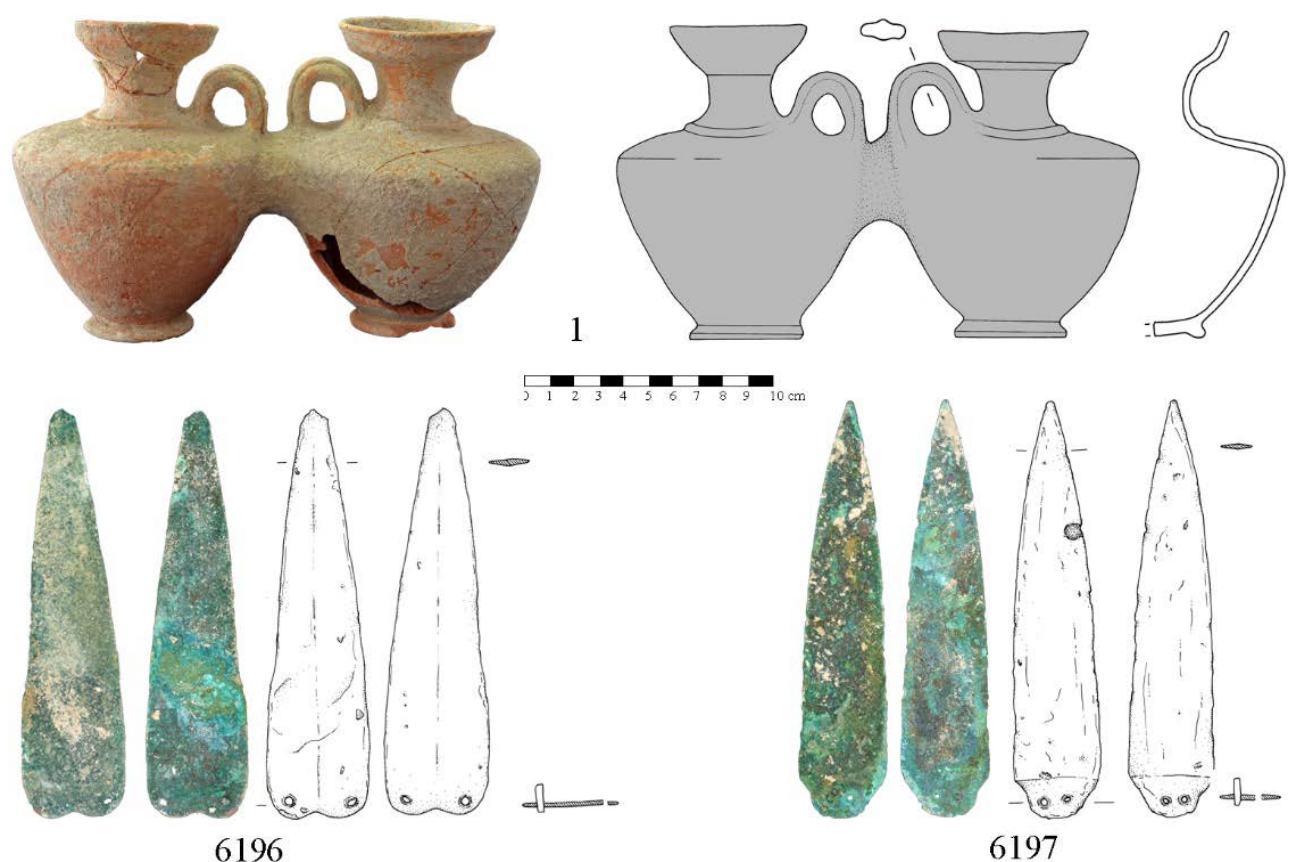

6197

Fig. 7 - Twin-vases 6085 and two bronze daggers from Chamber 1 of Tomb A1 (1:4). 
XIX (2015) Khalet al-Jam’a. A Middle Bronze and Iron Age necropolis near Bethlehem (Palestine)

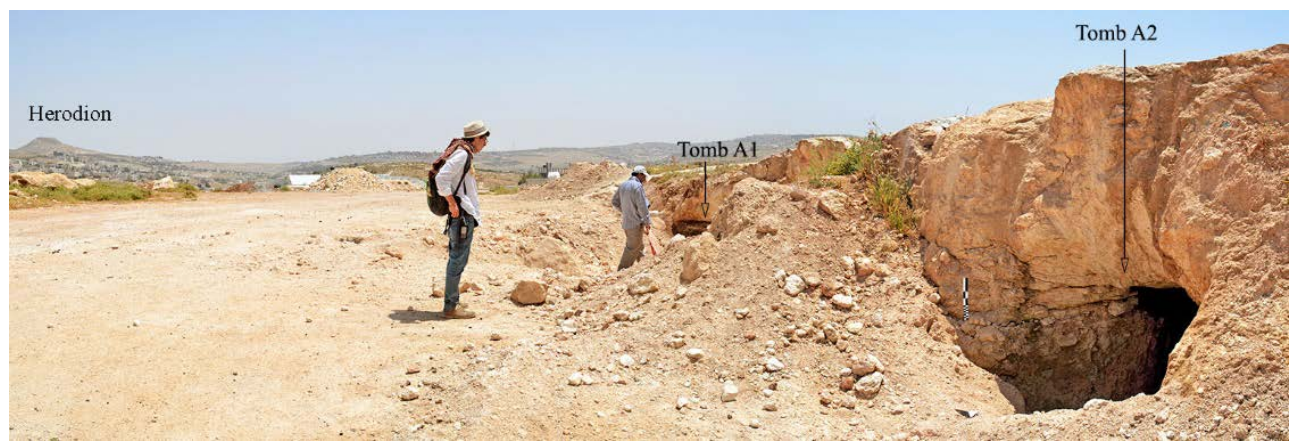

Fig. 8 - Cut Tombs A1 and A2; from the north.

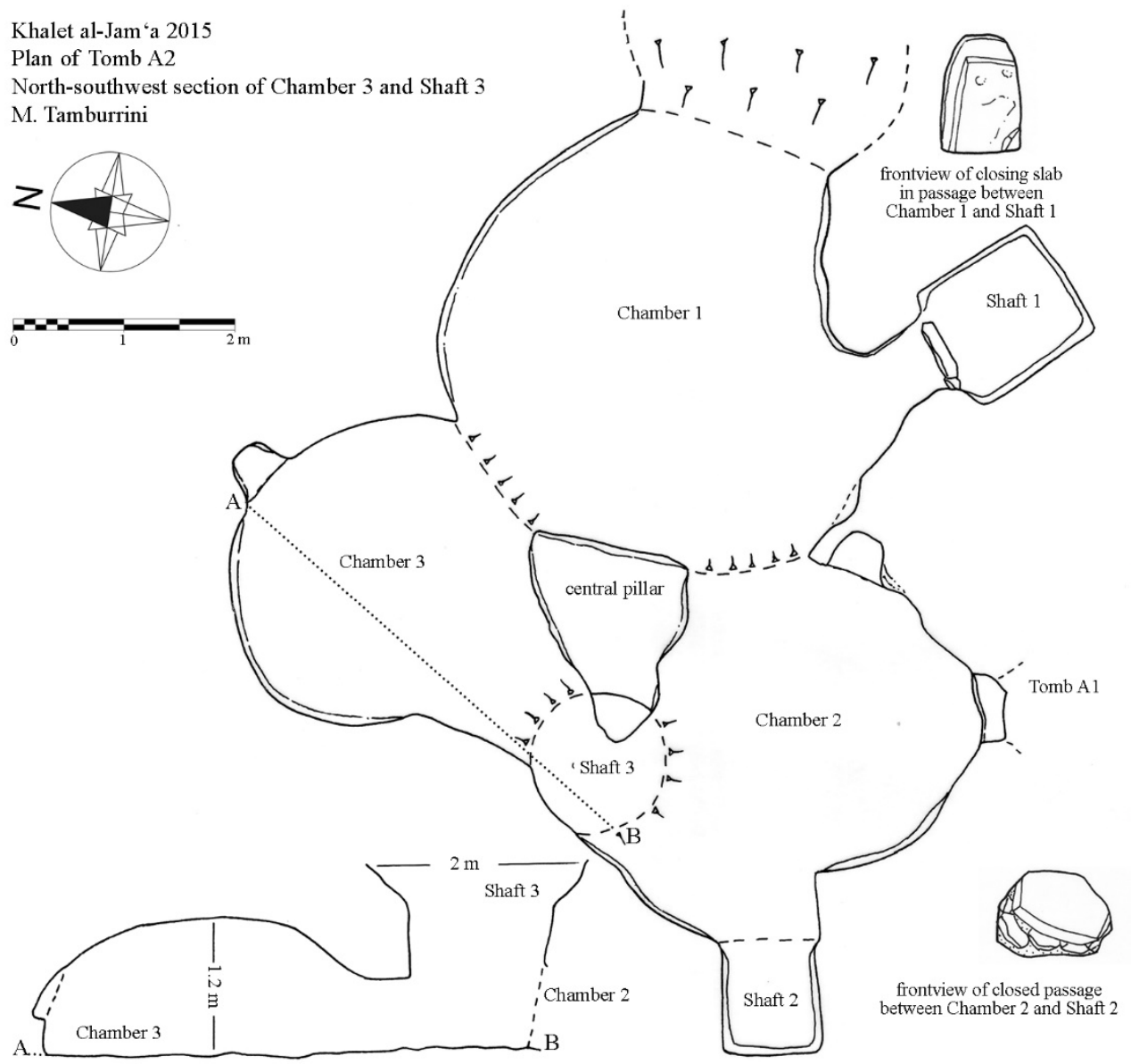

Fig. 9 - Plan and section of Tomb A2 (with front view of closure stones). 


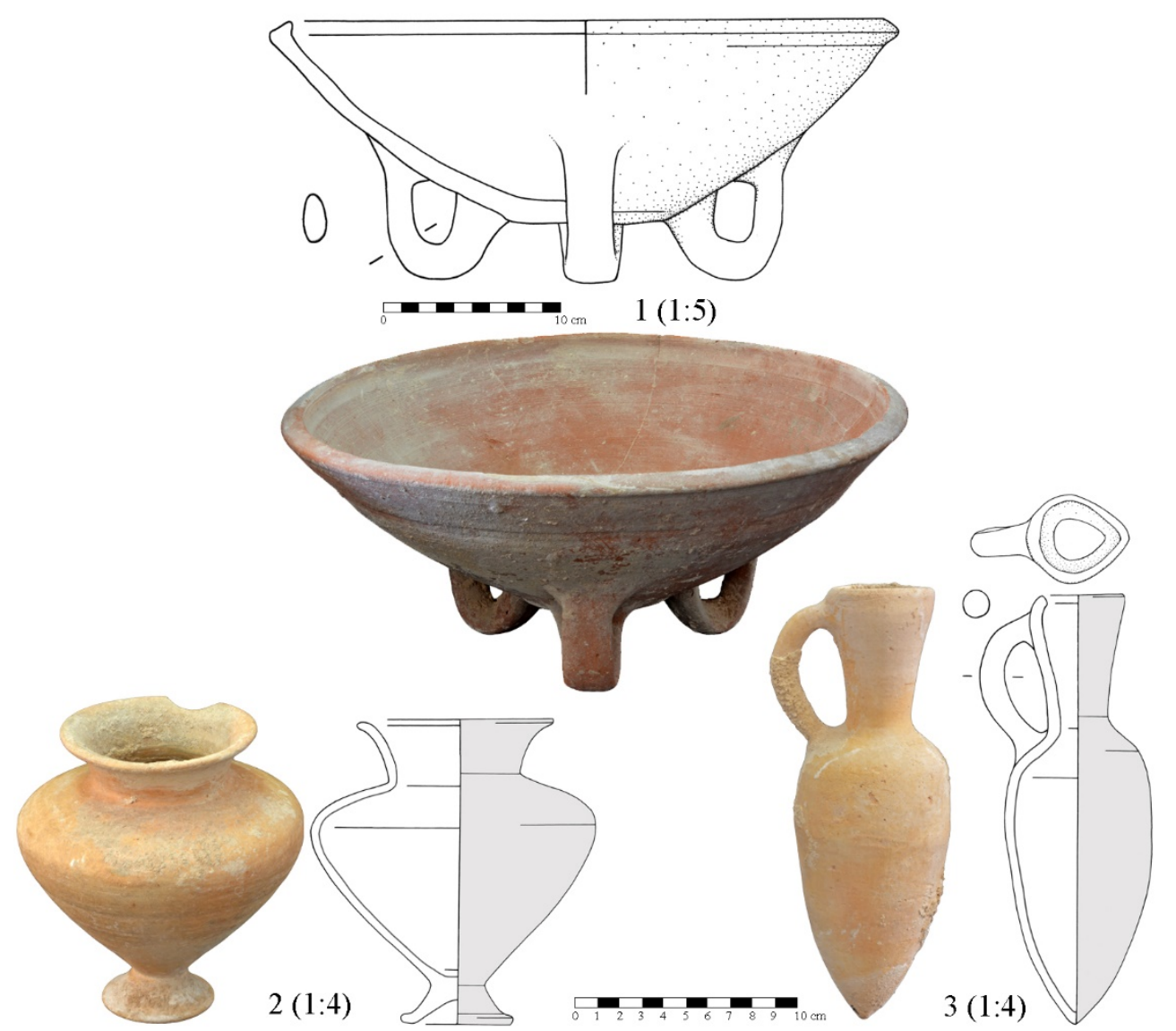

Fig. 10 - Middle Bronze pottery from Chamber 1 of Tomb A2.

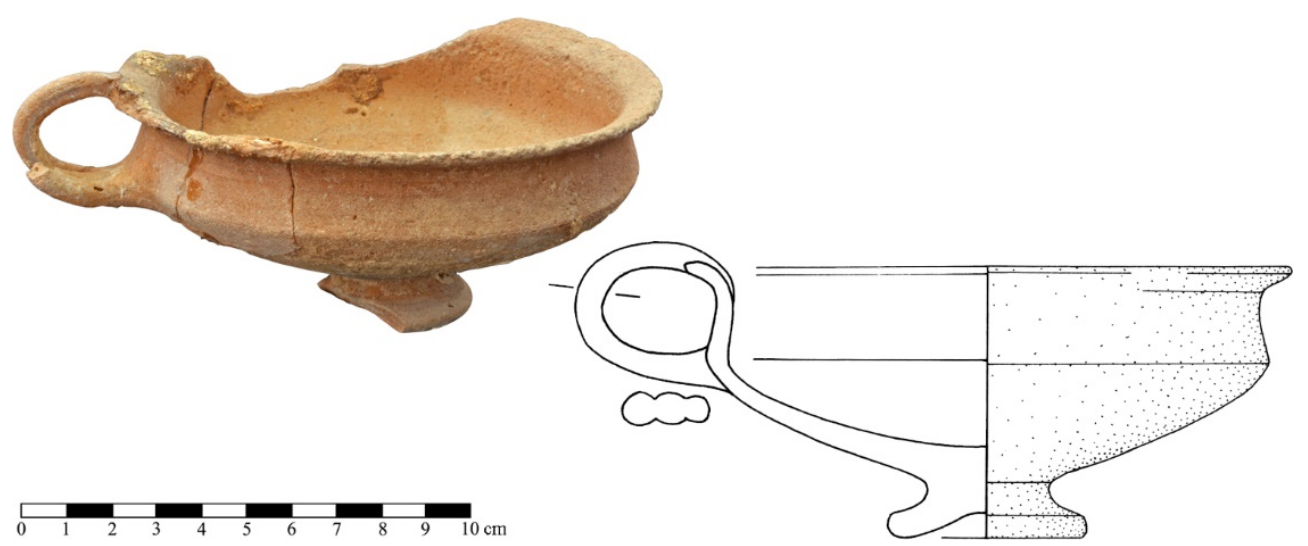

Fig. 11 - Pedestal vase 6077 from Chamber 1 of Tomb A2 (1:2). 
XIX (2015) Khalet al-Jam’a. A Middle Bronze and Iron Age necropolis near Bethlehem (Palestine)
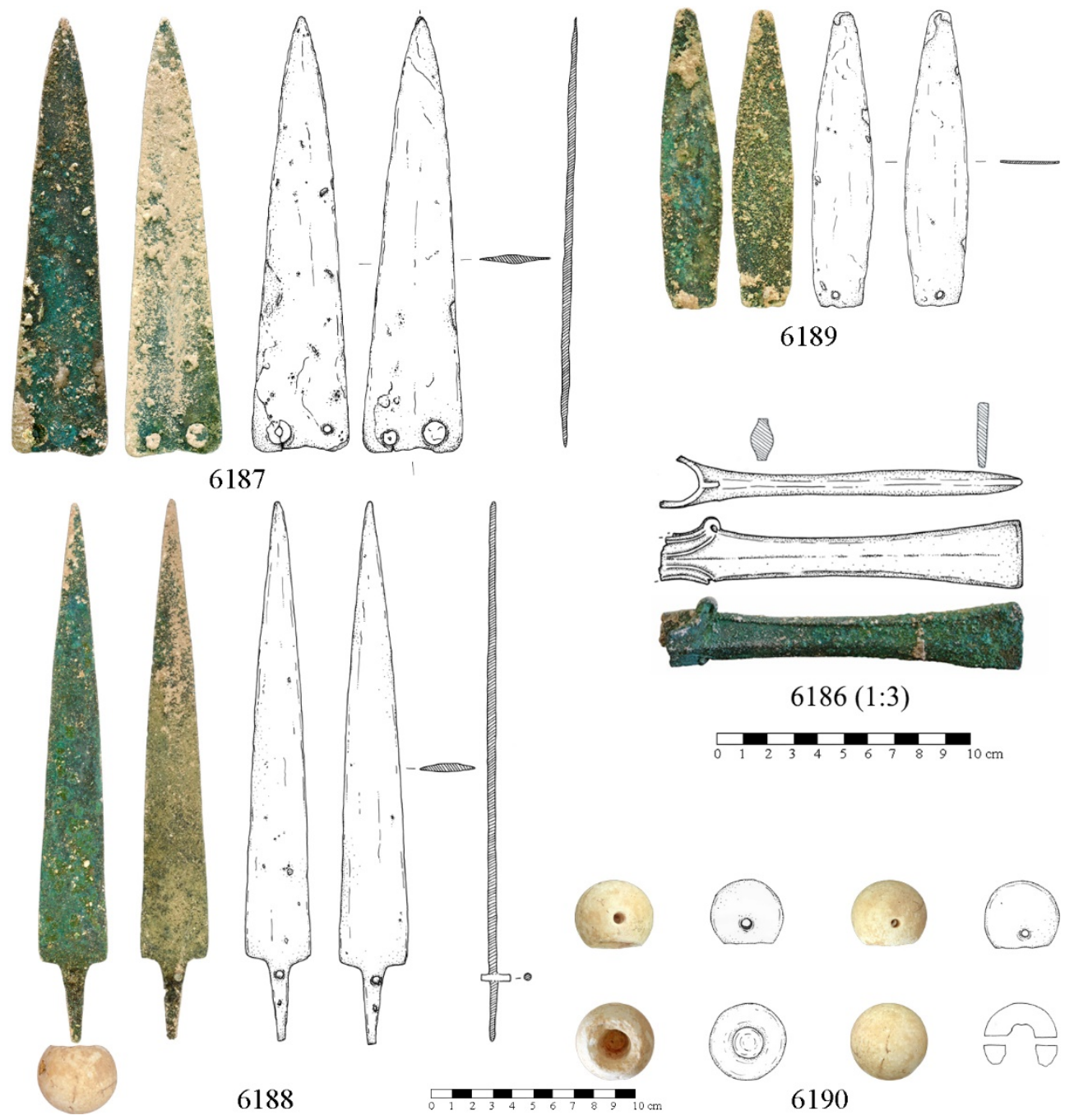

Fig. 12 - Daggers and pomel (1:4), axe (1:3) from Chamber 1 of Tomb A2.

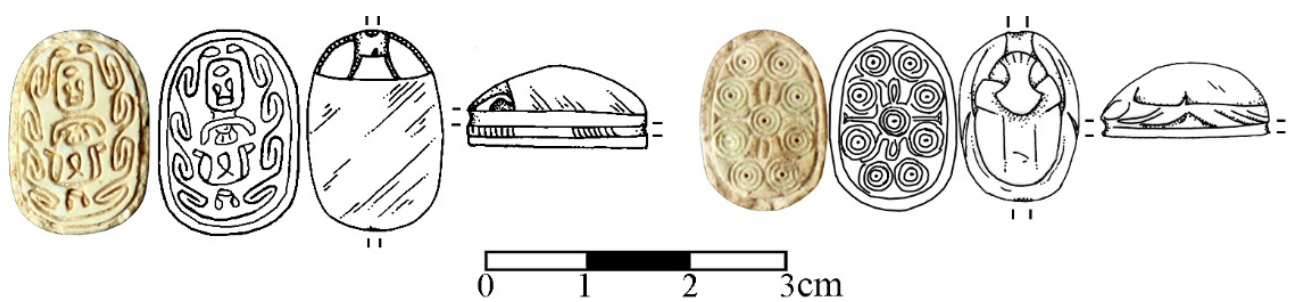

Fig. 13 - Scarabs from Chamber 1 of Tomb A2 (1:1). 

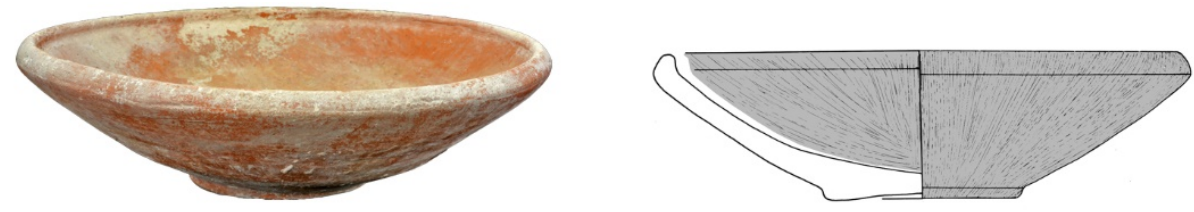

1

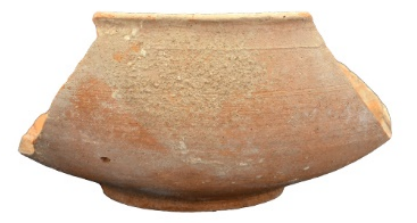

2

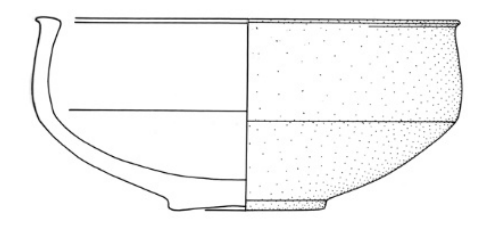

0
0
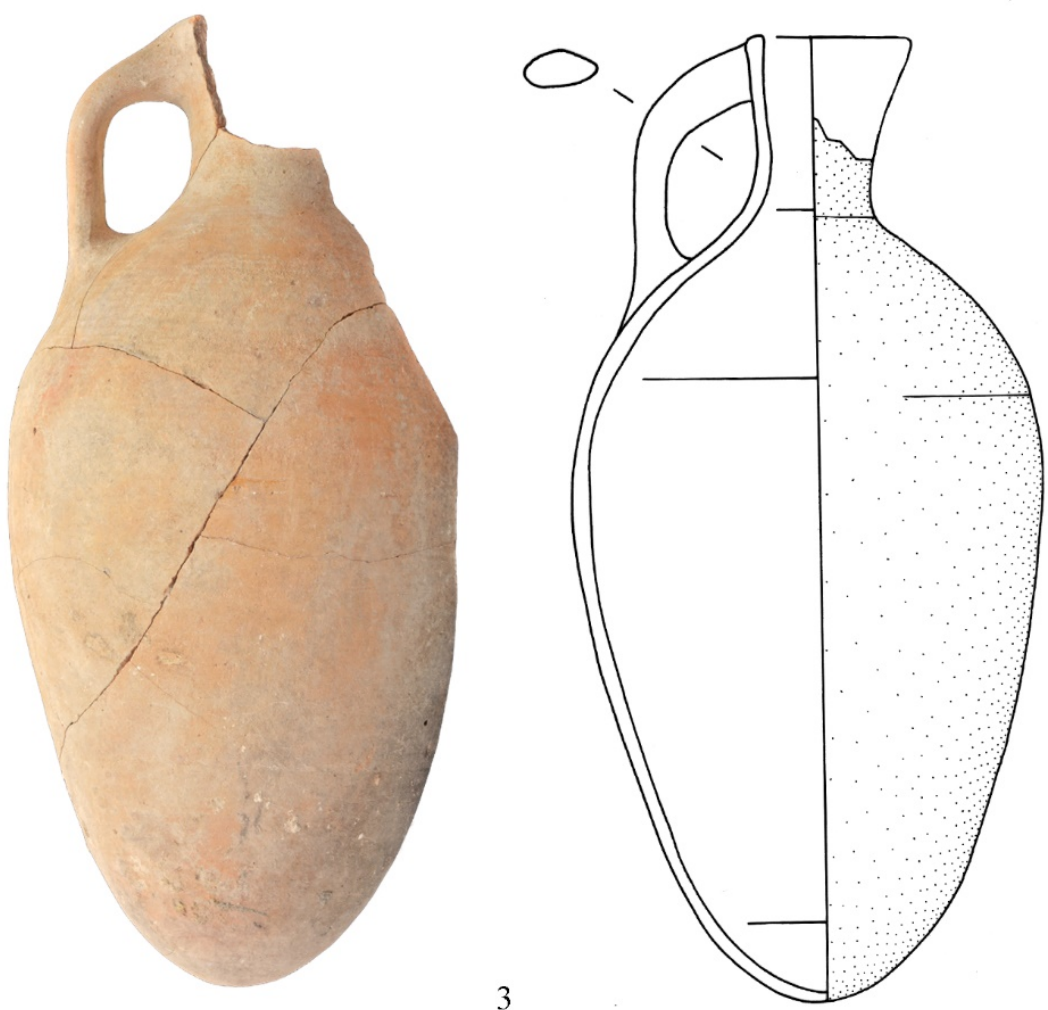

3

Fig. 14 - Middle Bronze pottery from Chamber 2 of Tomb A2 (1:4). 
XIX (2015) Khalet al-Jam’a. A Middle Bronze and Iron Age necropolis near Bethlehem (Palestine)

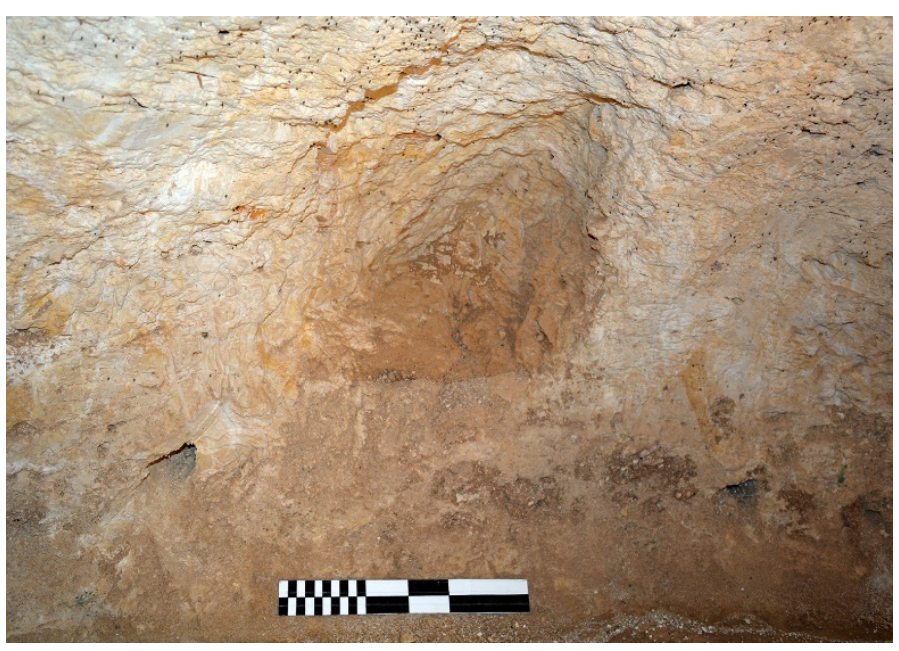

Fig. 15 - The niche on the north-eastern side of Chamber 3 of Tomb A2; from the southeast.

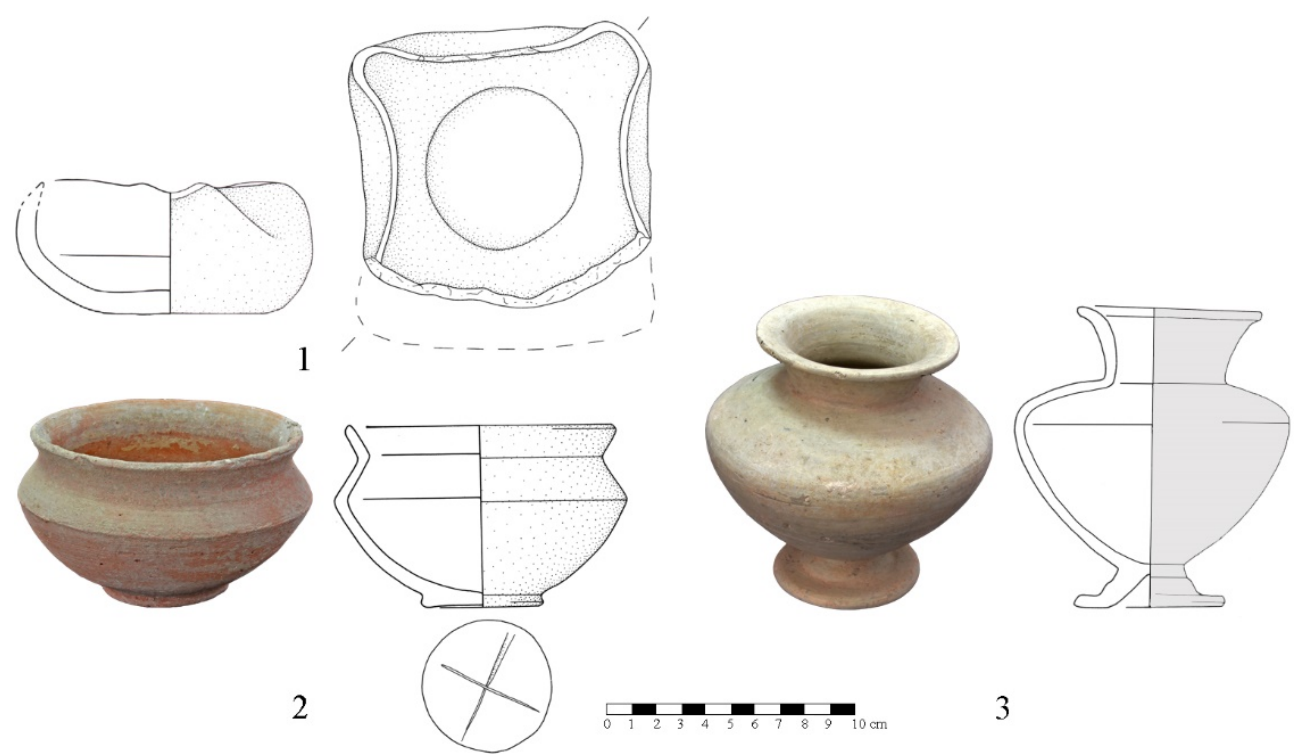

Fig. 16 - Early Bronze IV (n. 1) and Middle Bronze (ns. 2-3) pottery from Chamber 3 of Tomb A2 (1:4). 

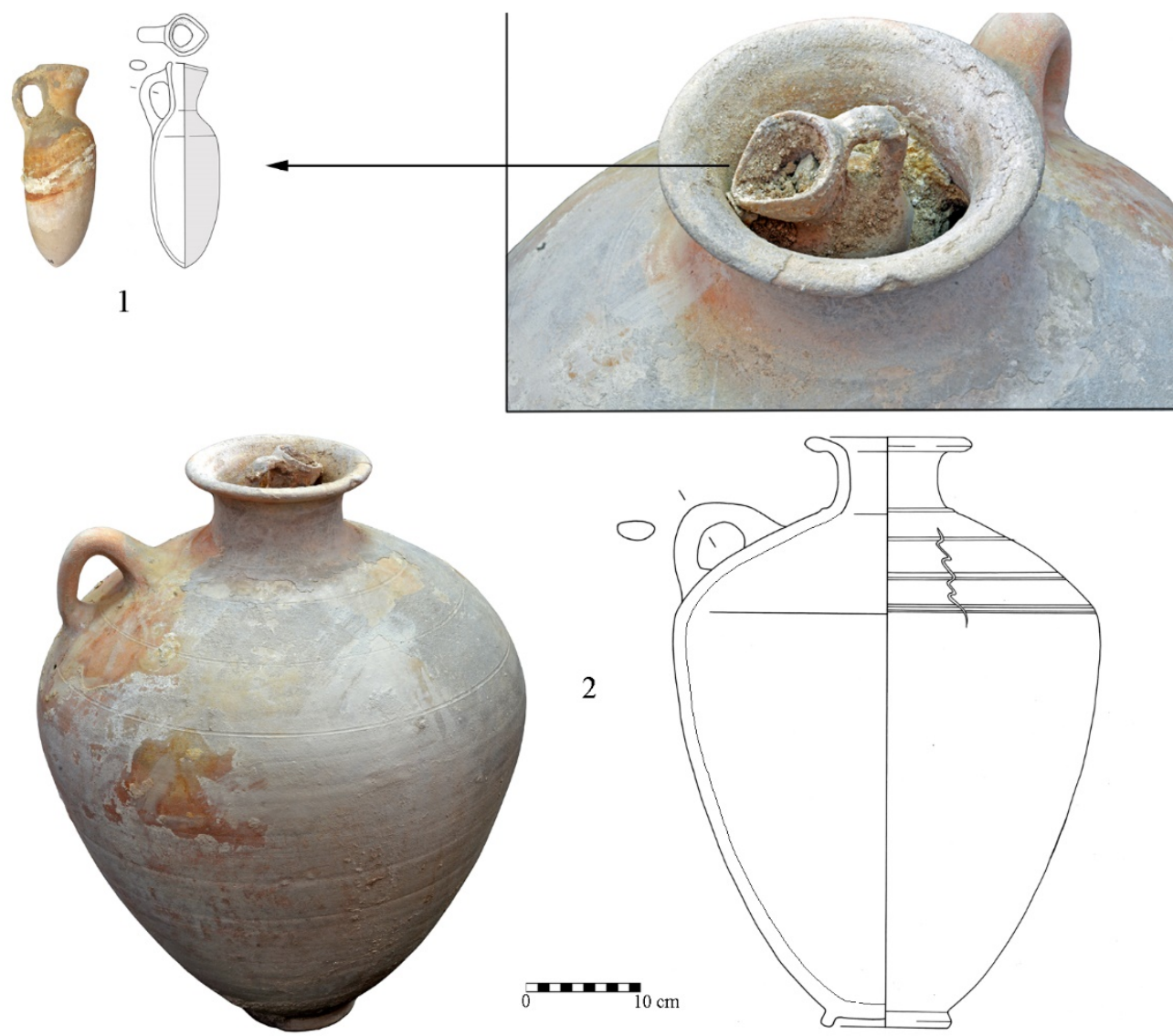

Fig. 17 - Dipper juglet 6243 and jar 6233, retrieved one inside the other, from Chamber 3 of Tomb A2 (1:4).

Fig. 18 - Tomb A3 from the south-east.

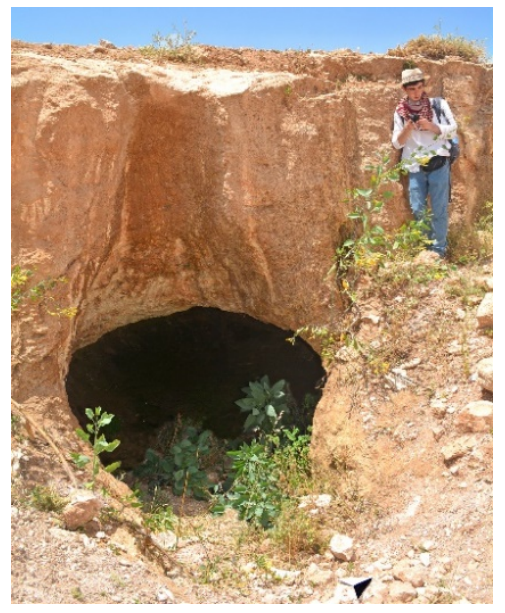


XIX (2015) Khalet al-Jam’a. A Middle Bronze and Iron Age necropolis near Bethlehem (Palestine)

Fig. 19 - Tomb A4 from the south-east.

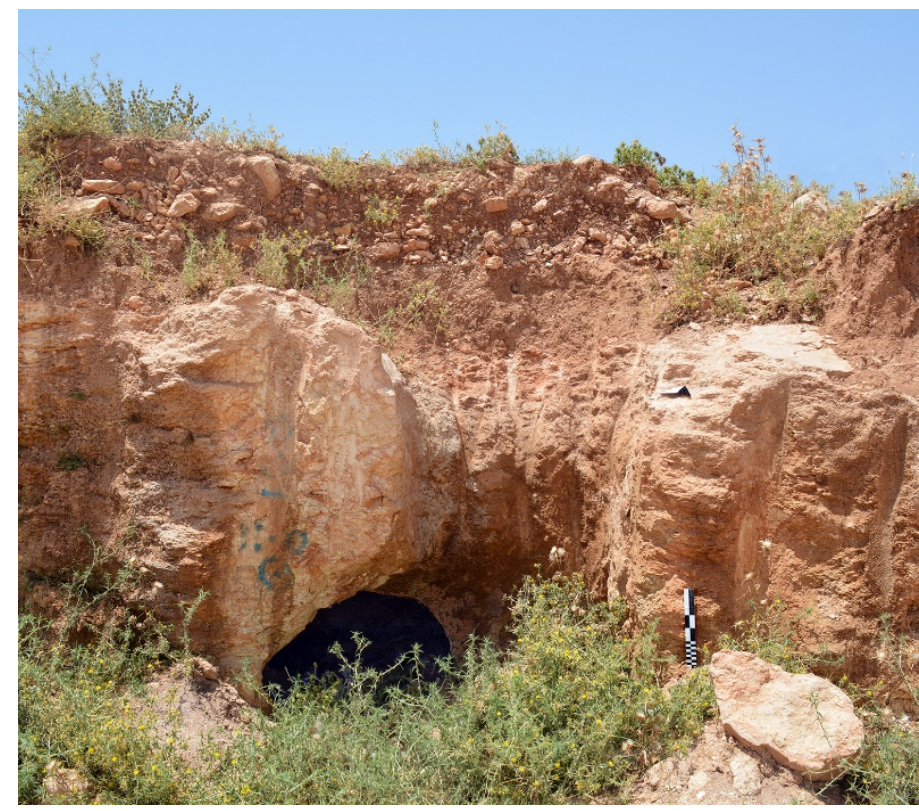

Fig. 20 - Shaft of Tomb A7, in the foreground, and the Herodion, in the background; from the south-west.

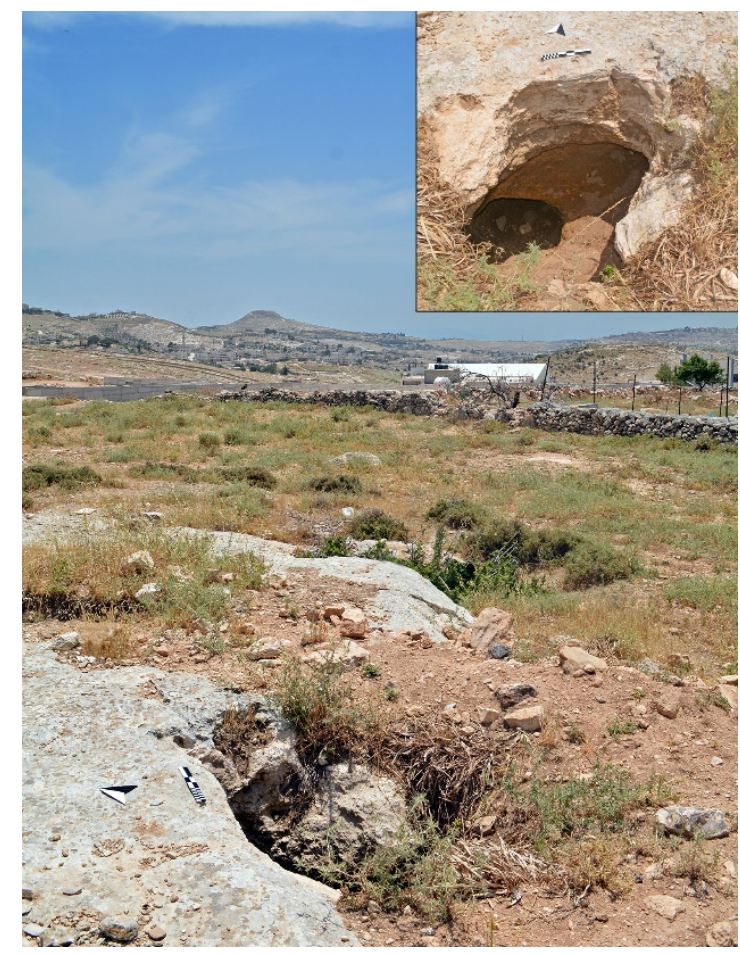




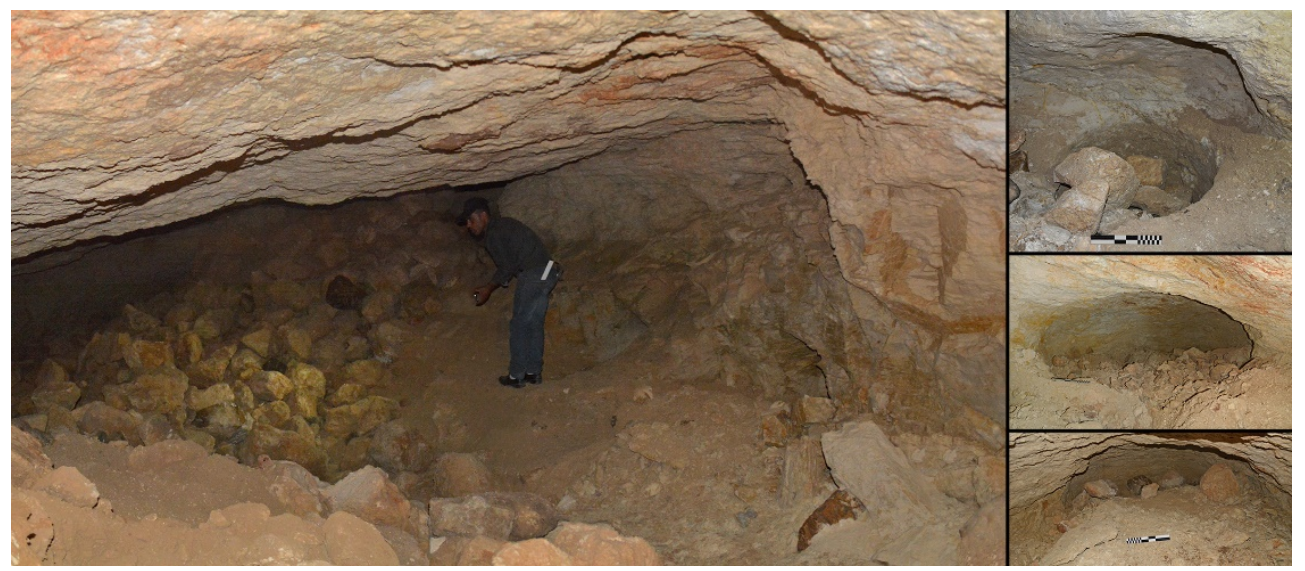

Fig. 21 - Underground chamber, left, and small partition, right, of Tomb A7.
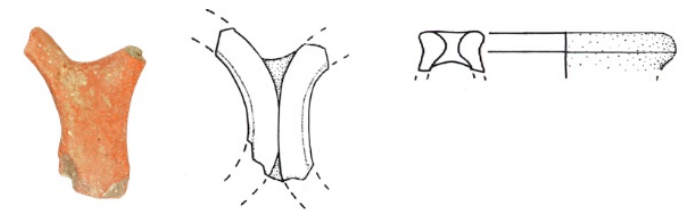

1
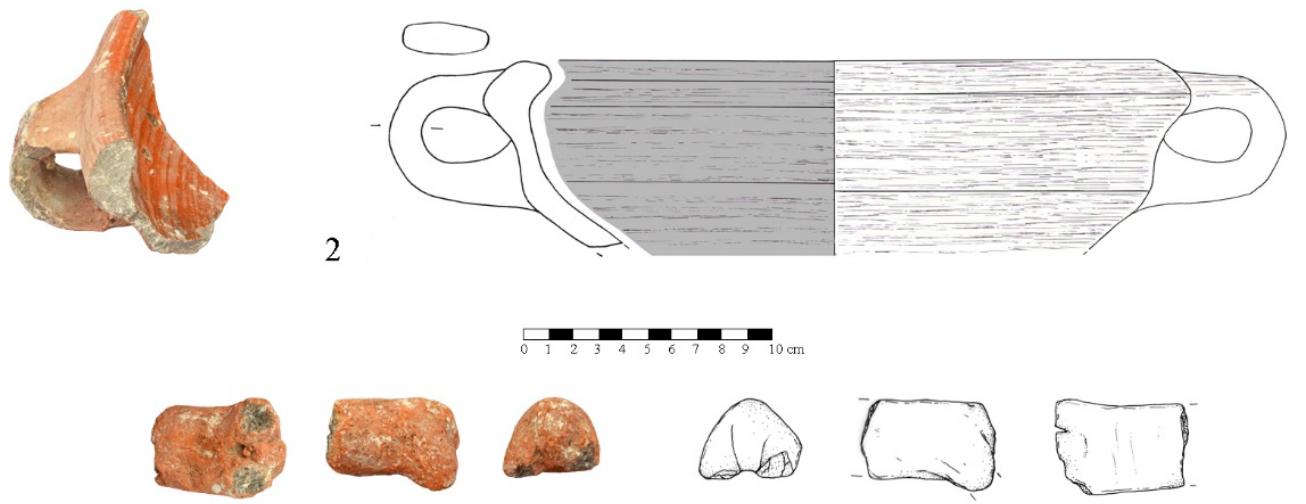

\section{KJ.15.TA7/d}

Fig. 22 - Iron Age pottery, and clay figurine from Tomb A7 (1:4). 
XIX (2015) Khalet al-Jam’a. A Middle Bronze and Iron Age necropolis near Bethlehem (Palestine)
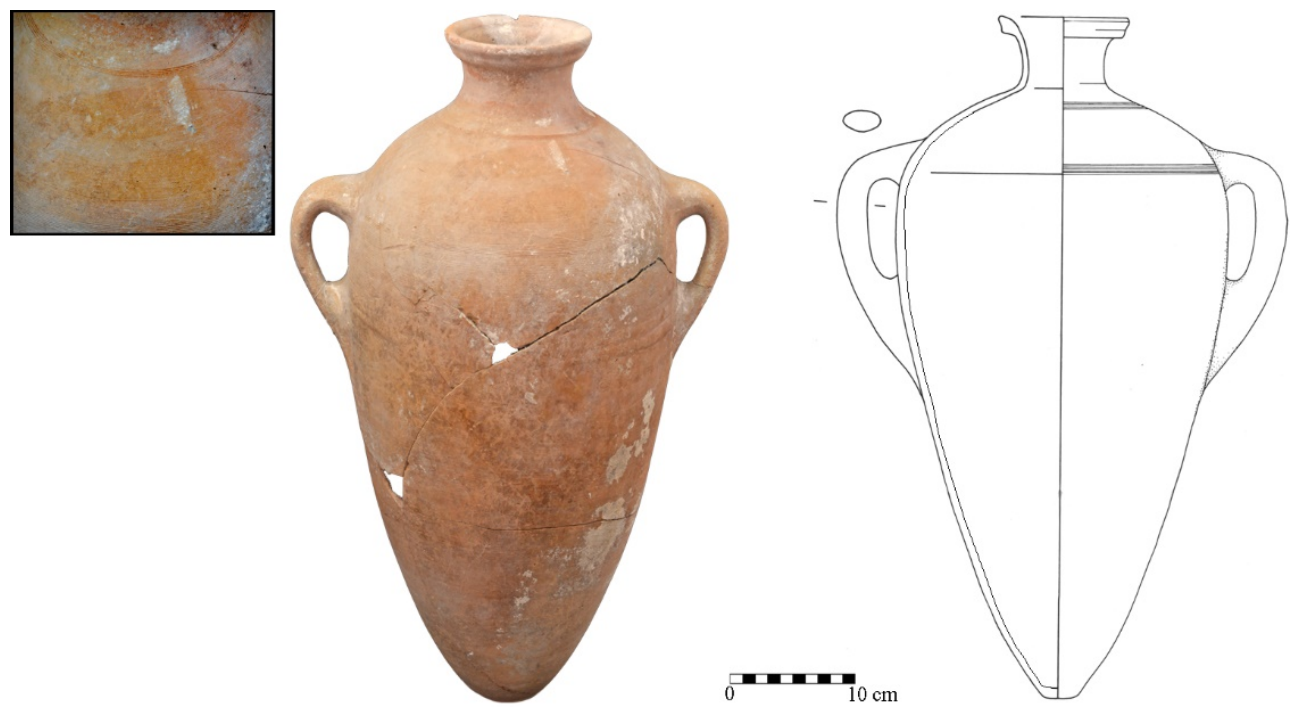

Fig. 23 - Jar 6236 from Chamber 1 of Tomb B9 (1:8).

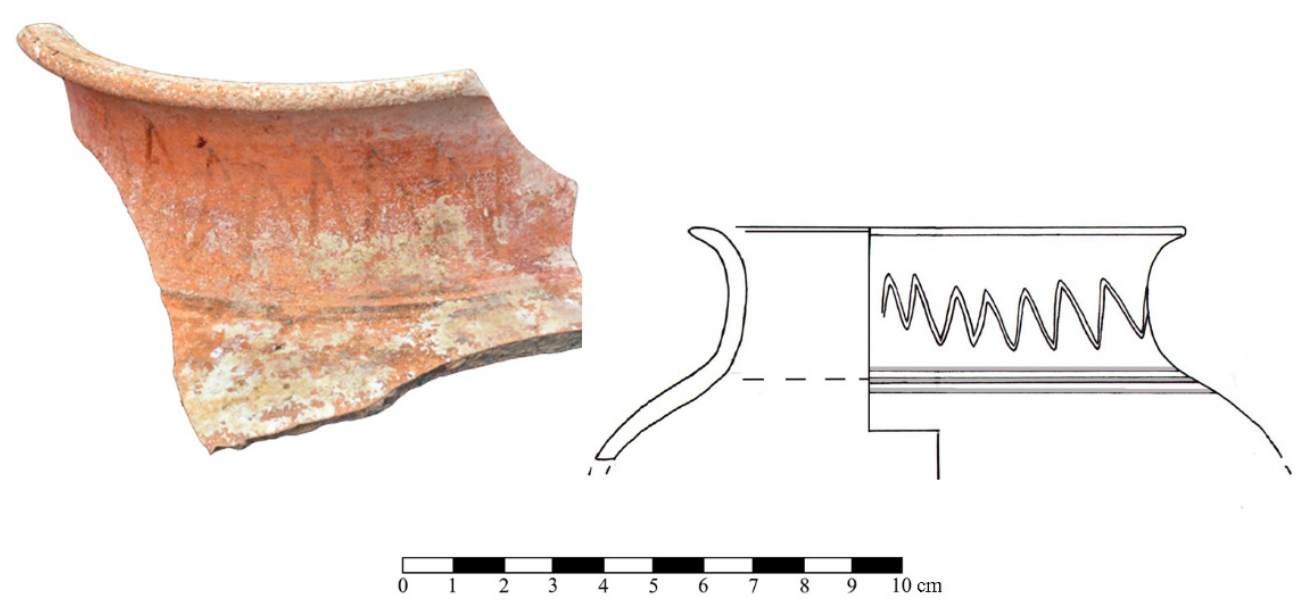

Fig. 24 - Jar KJ.15.TB1.2/2 from Chamber 1 of Tomb B9 (1:2). 


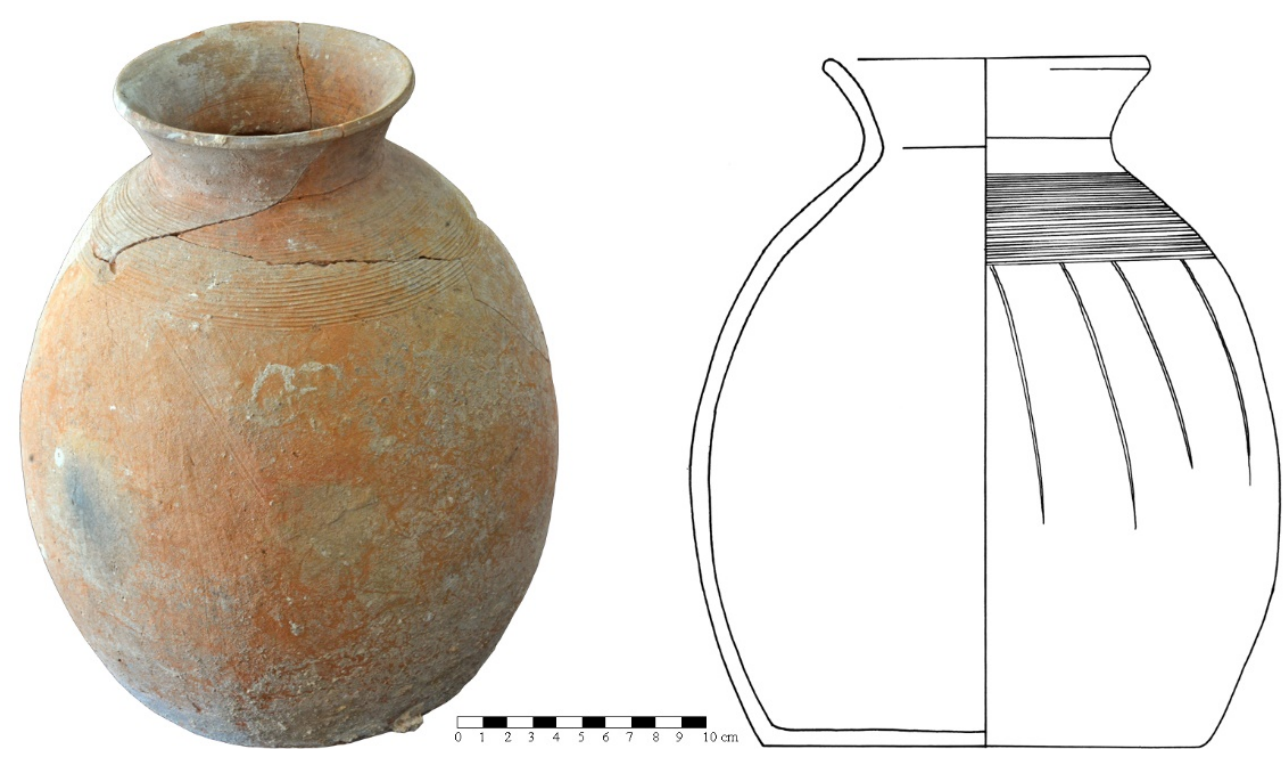

Fig. 25 - Early Bronze IVB jar 6173 from Tomb B10 (1:4).

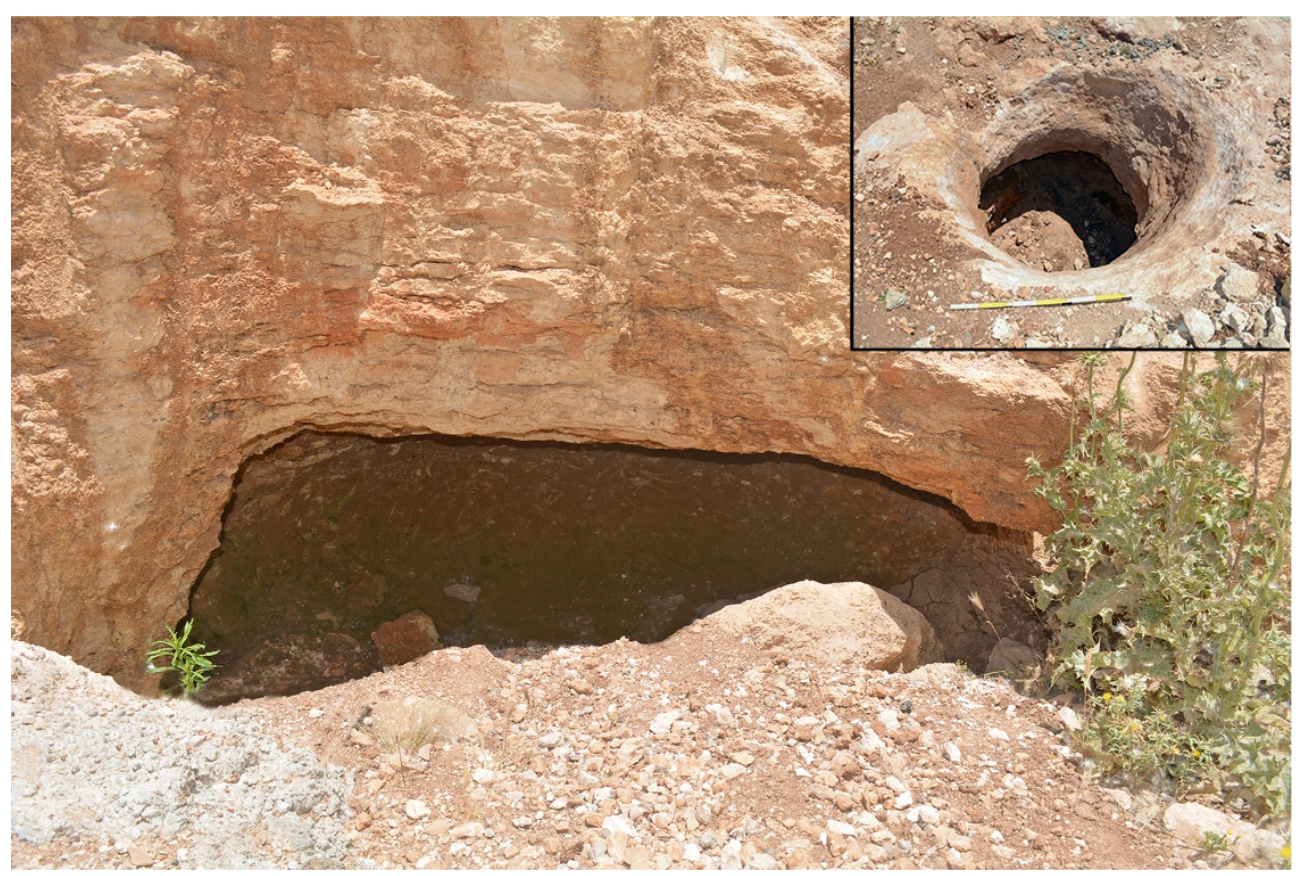

Fig. 26 - Tomb B11 from the south. 
XIX (2015) Khalet al-Jam’a. A Middle Bronze and Iron Age necropolis near Bethlehem (Palestine)
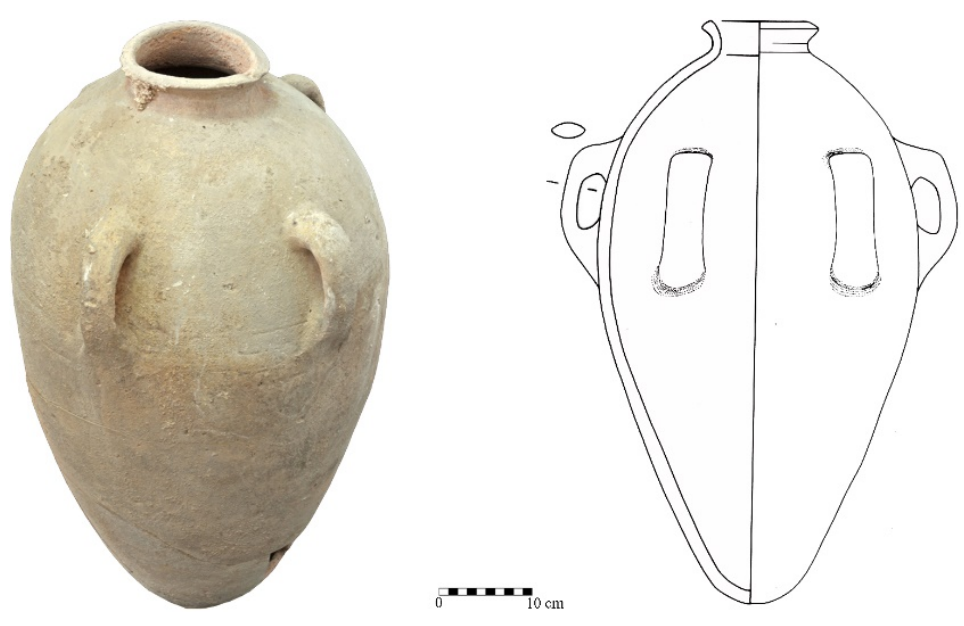

Fig. 27 - Jar 6249 from Tomb B11.

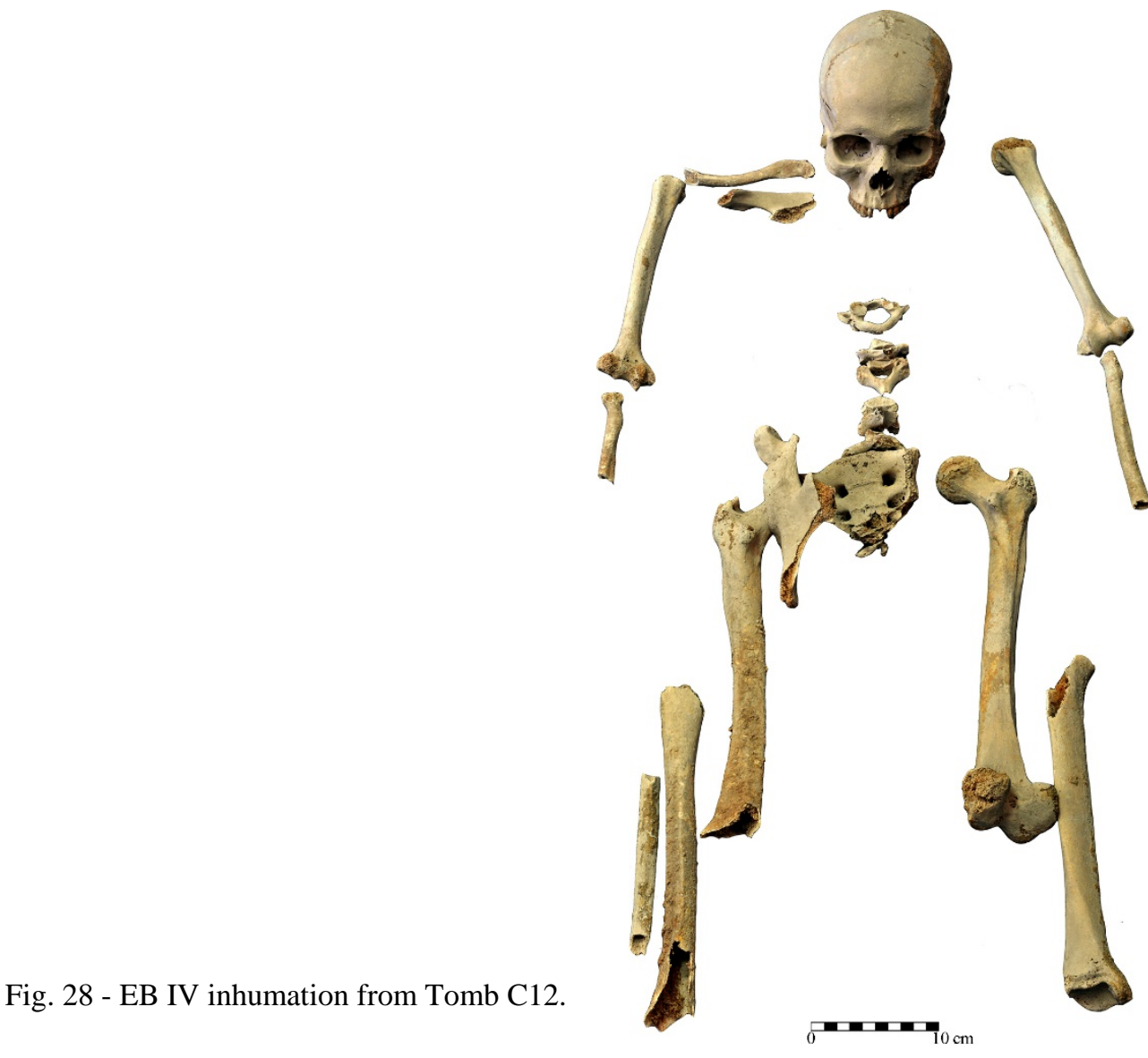



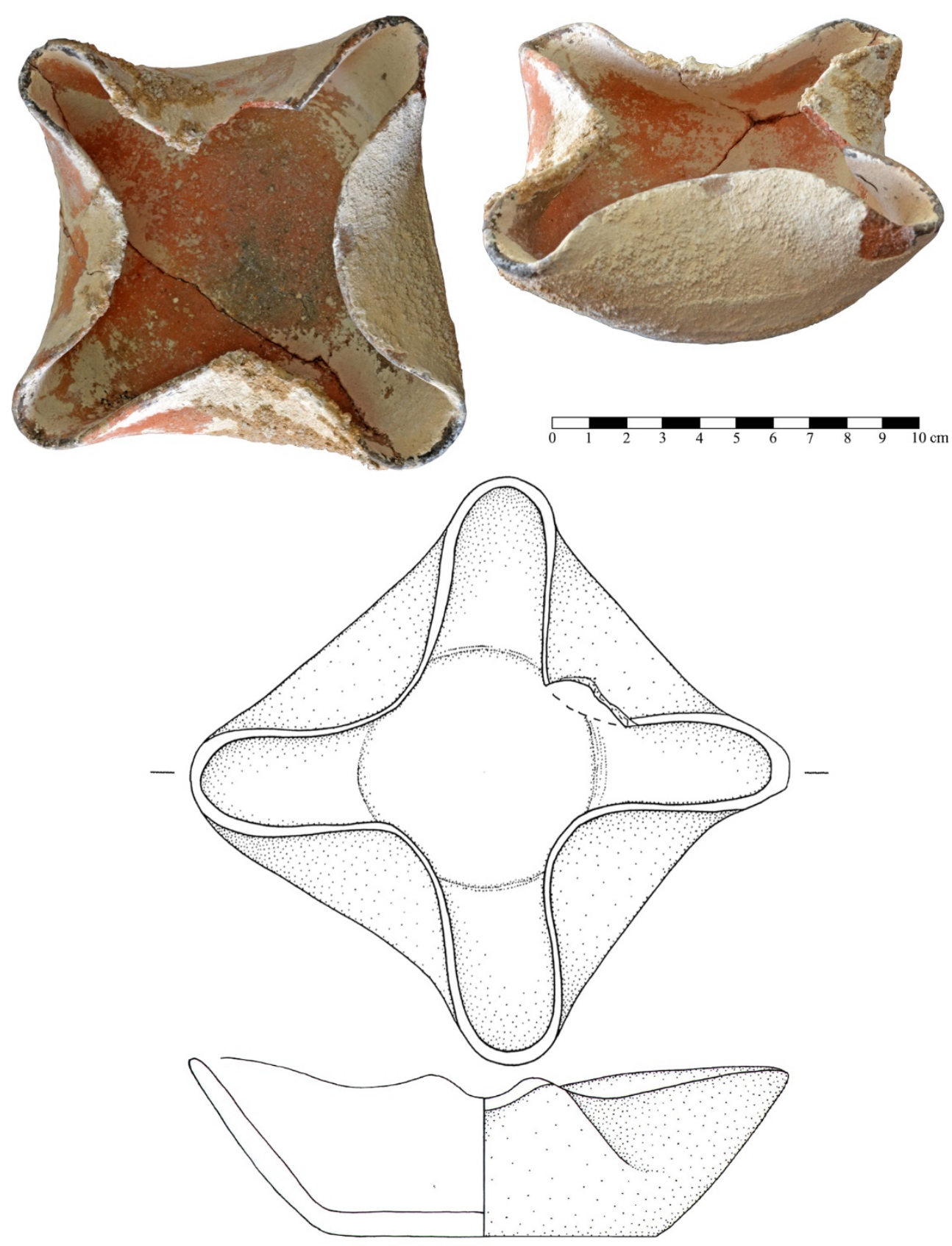

Fig. 29 - Early Bronze IV four spouted lamp 6040 from Tomb C12 (1:2). 


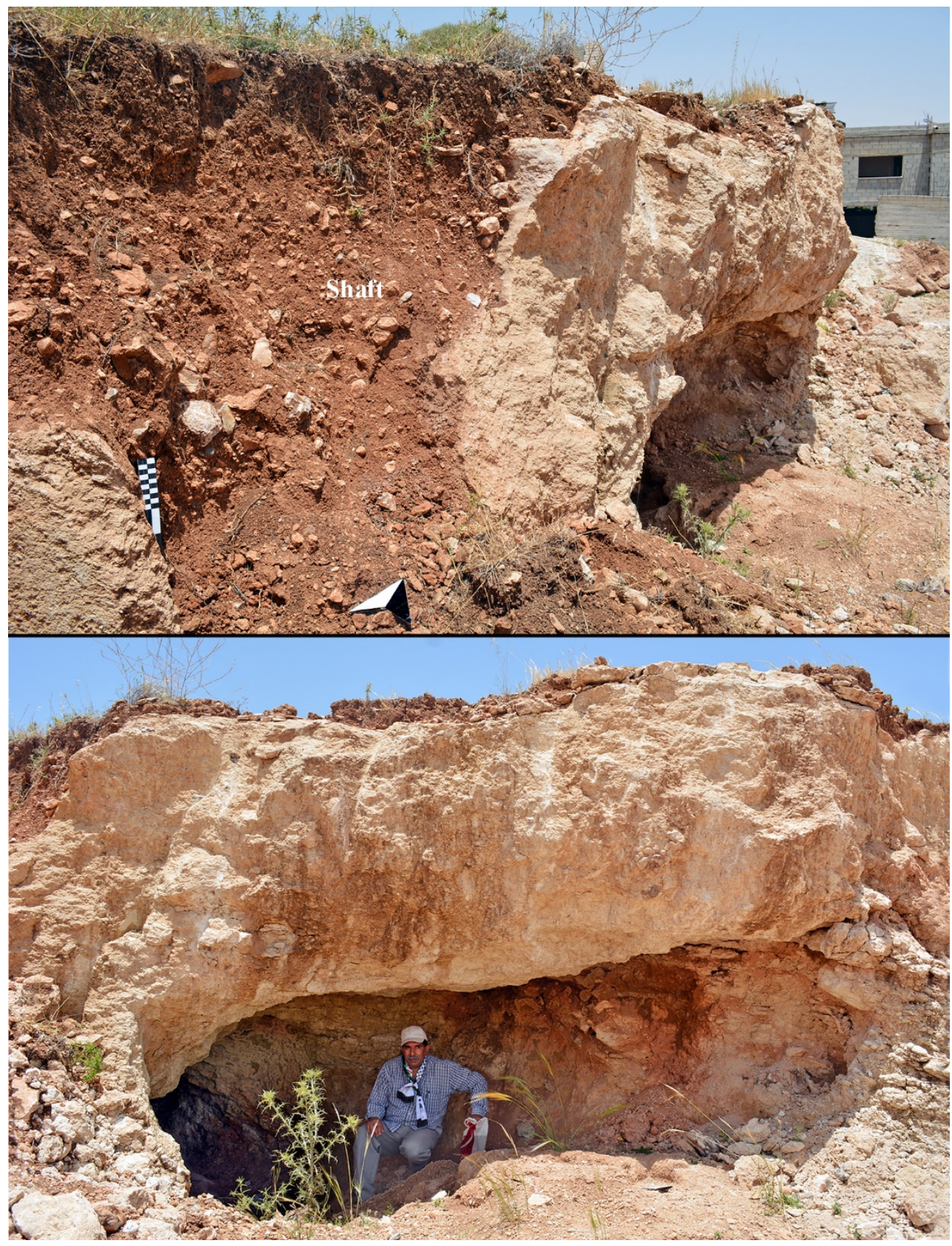

Fig. 30 - Shaft of Barmils' Tomb in Area D (top), from the south-east; main chamber of Barmils' Tomb (down), from the south-east. 

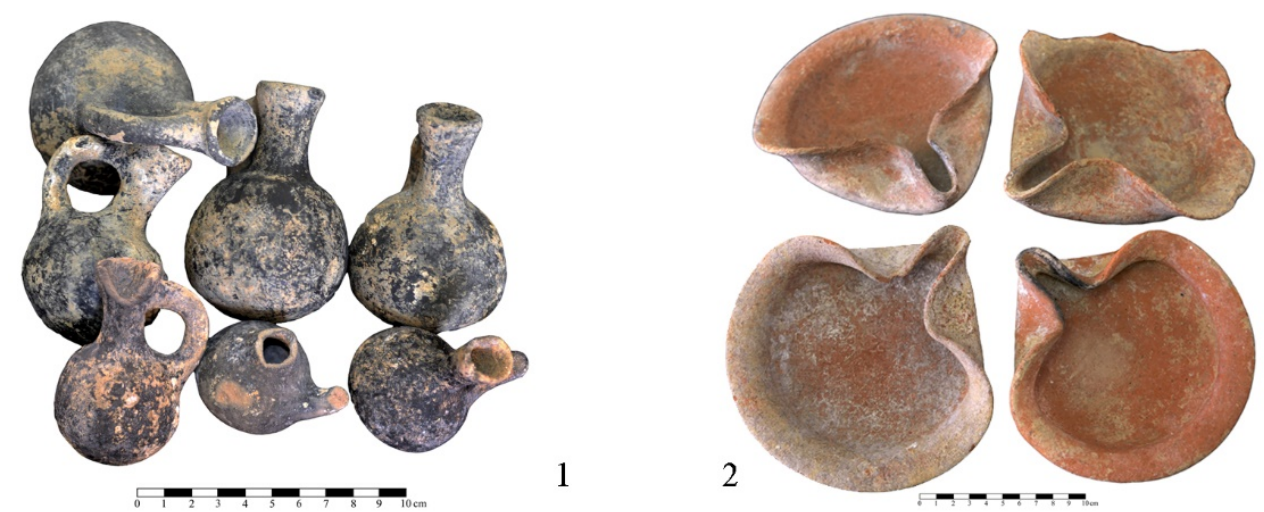

Fig. 31 - Iron Age Black Ware juglets (n. 1), and lamps (n. 2) from Barmils’ Tomb.

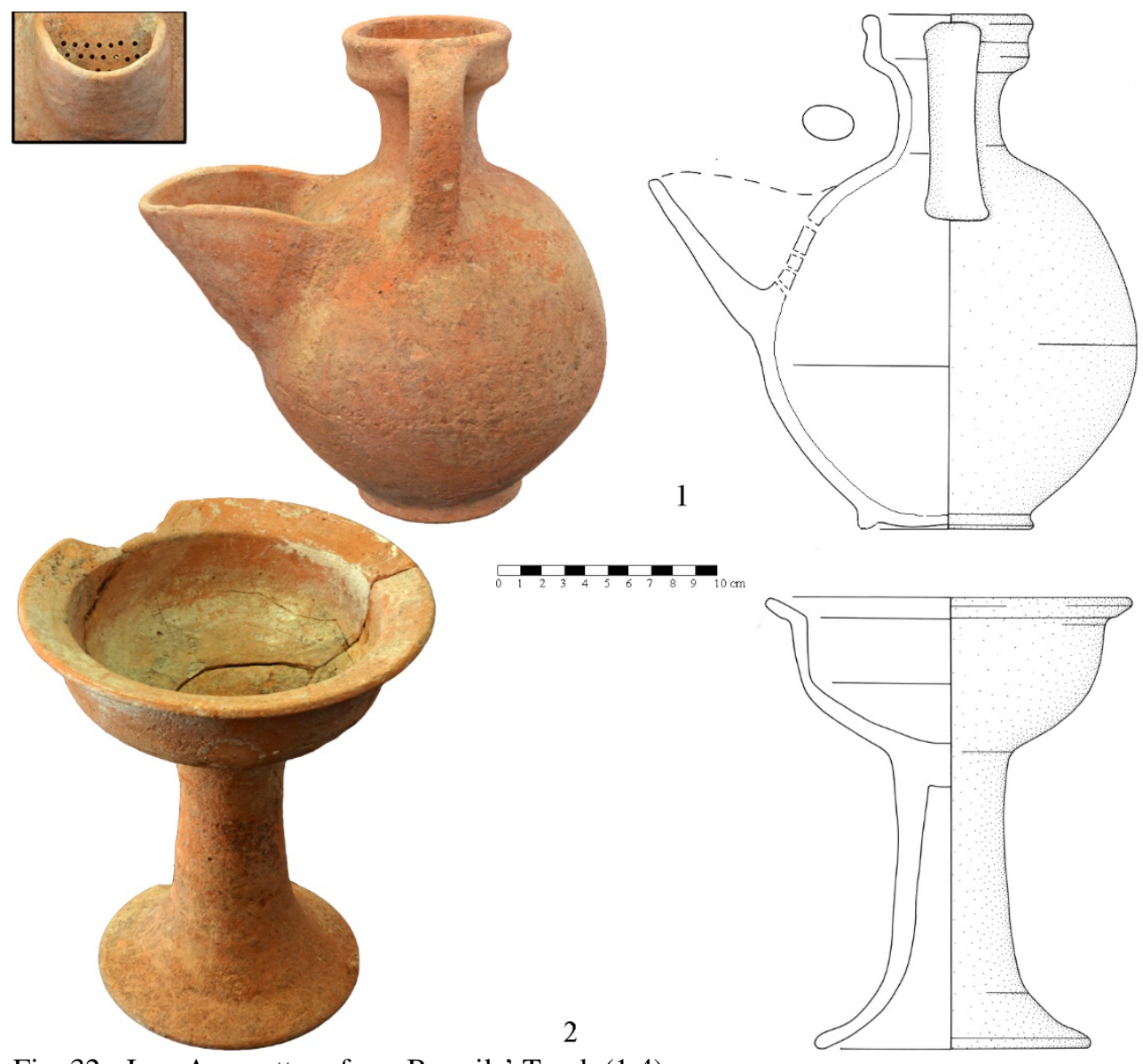

Fig. 32 - Iron Age pottery from Barmils’ Tomb (1:4). 
XIX (2015) Khalet al-Jam’a. A Middle Bronze and Iron Age necropolis near Bethlehem (Palestine)

Fig. 33 - Sketch plan of Area A with wine press and tower.

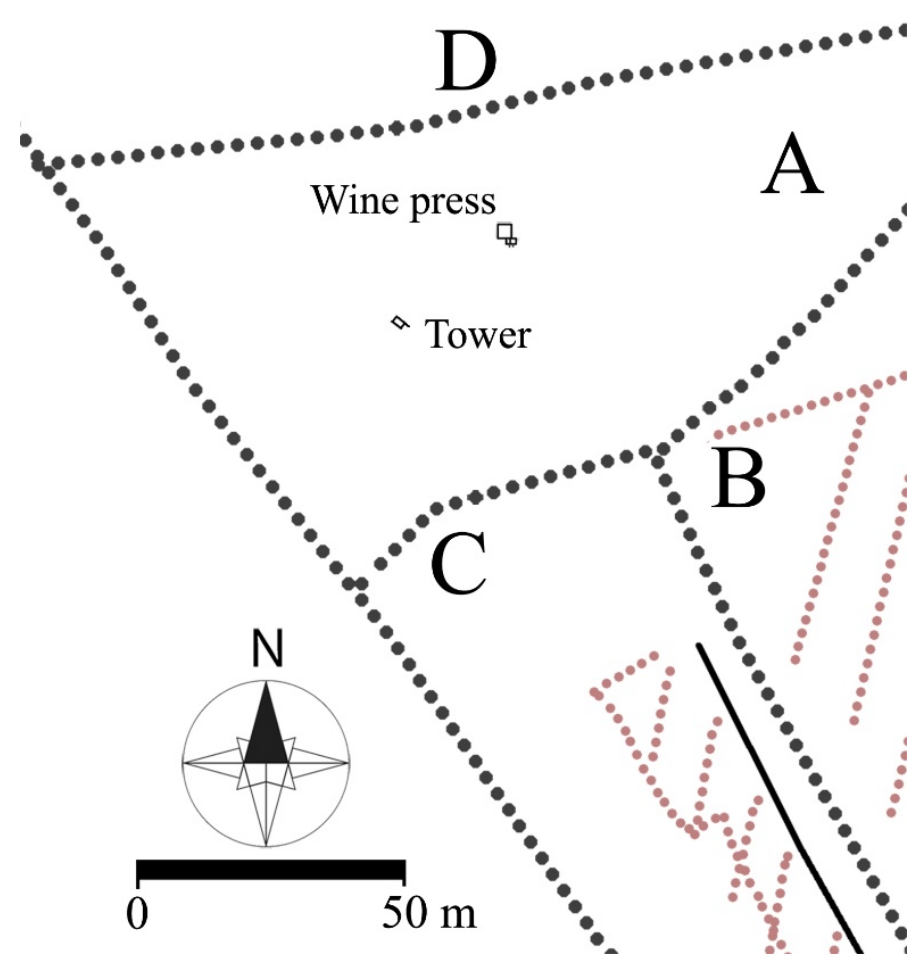

Fig. 34 - Wine press of Area A, in the foreground, and Herodion in the background; from the north.

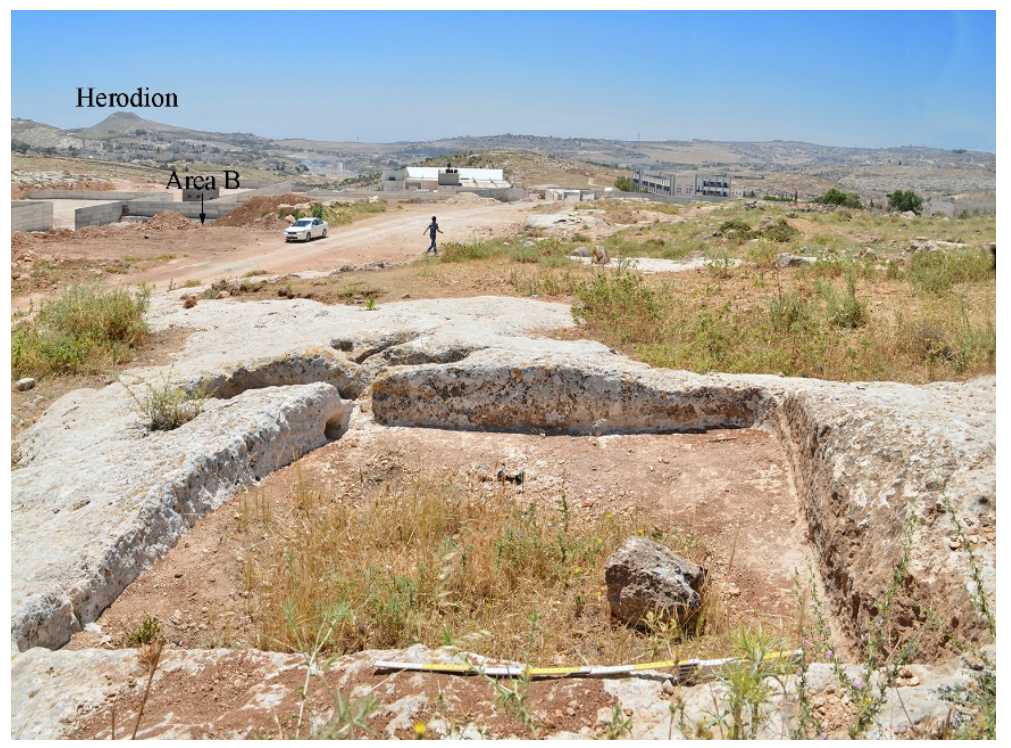




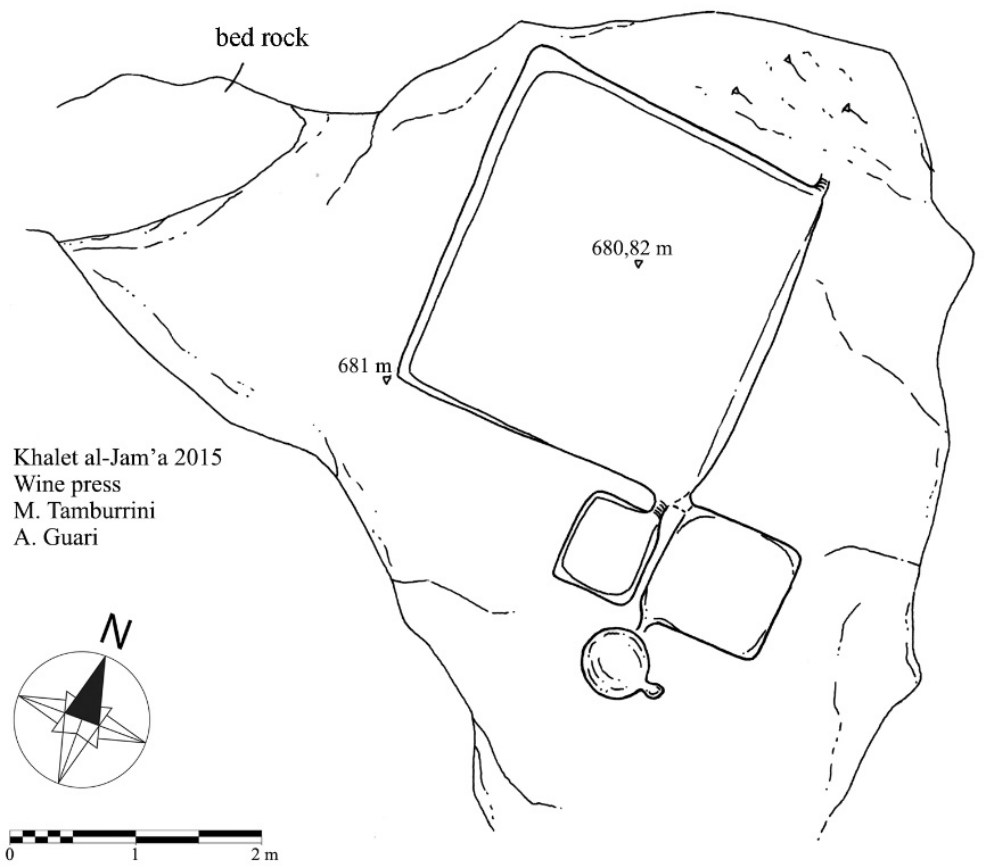

Fig. 35 - Plan of the wine press in Area A.

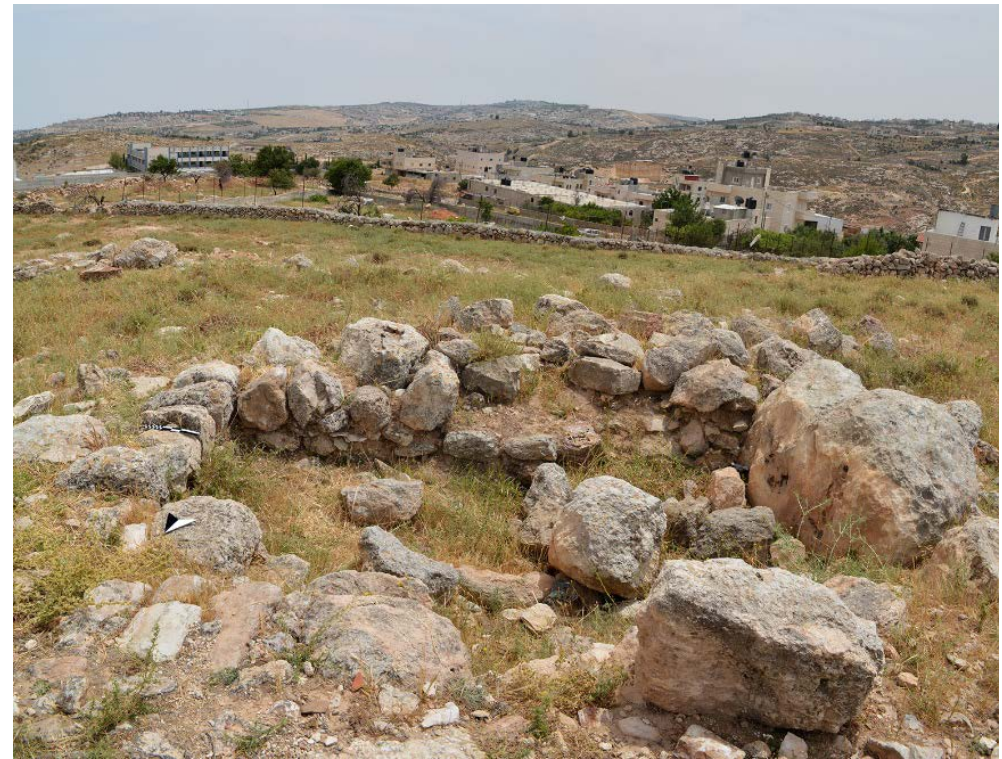

Fig. 36 - Iron Age tower of Khalet al-Jam'a; from the north-east. 
XIX (2015) Khalet al-Jam'a. A Middle Bronze and Iron Age necropolis near Bethlehem (Palestine)

\section{ARABIC ABSTRACT}

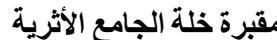

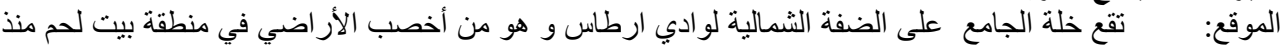

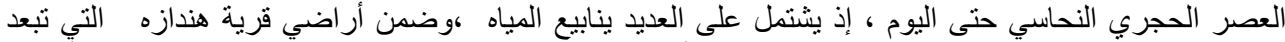

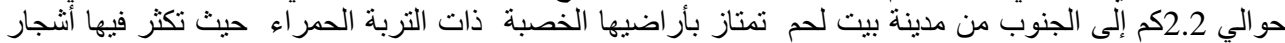

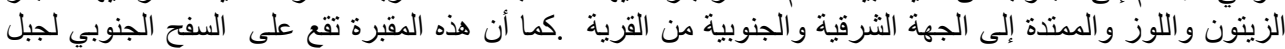

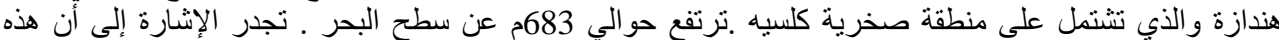

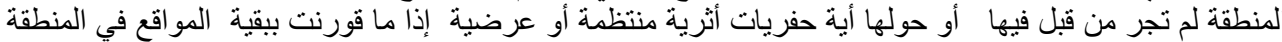

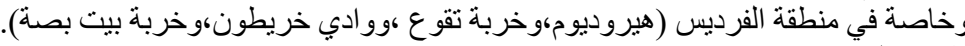
طريقة الكثف في منف

بناء على الاتصال الهاتفي الذي تلقاه مدير آثار بيت لحم (السيد محمد غياظة )من قبل الثرطة السياحية بتاريخ

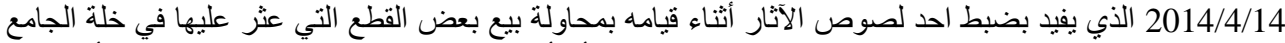

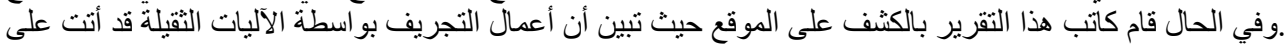

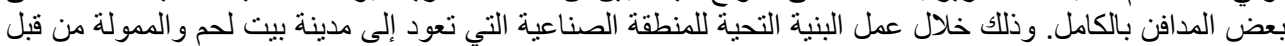

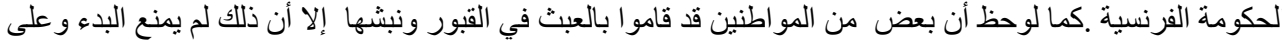

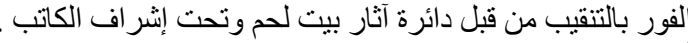

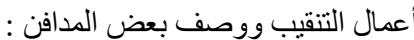

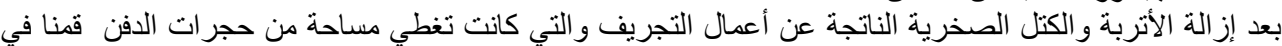

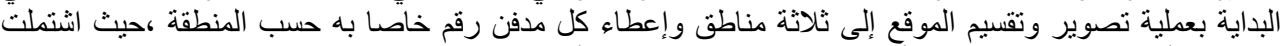

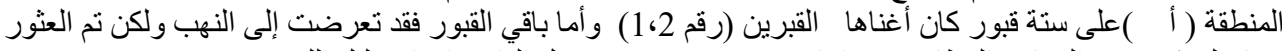

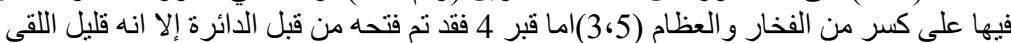

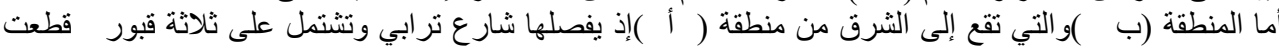

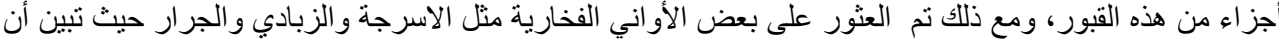

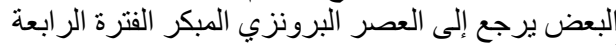

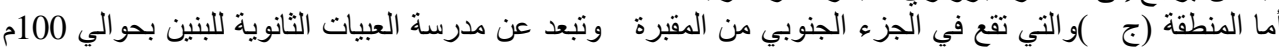

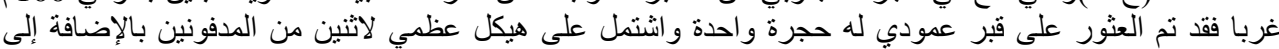
سر اجين وكسر لأو اني فخارية الإنية تجدر الإشارة إلى أن أعمال الحفر تم توخي الدقة فيها قد الإمكان من حيث تصوير اللقى الأثرية بعد الكثف عنها وقبل

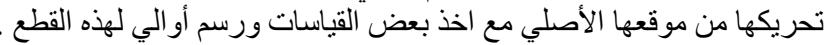

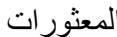

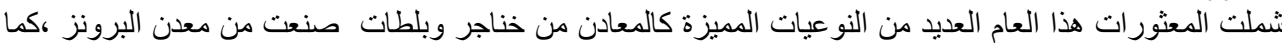

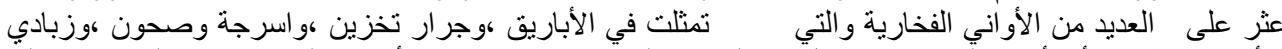

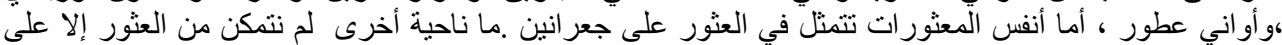

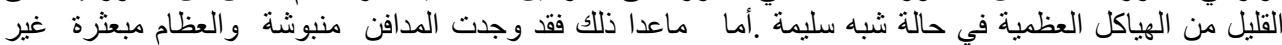

واضحة المعالم الخائرل الخلاصة

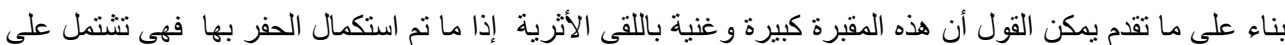

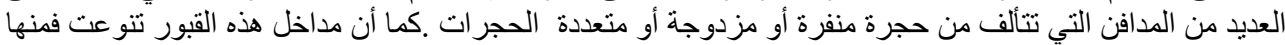

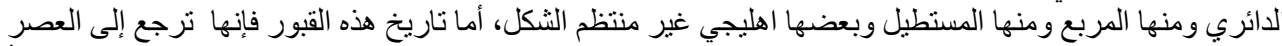

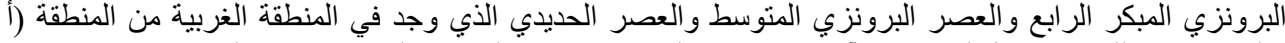

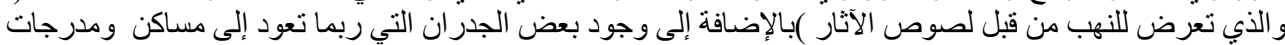

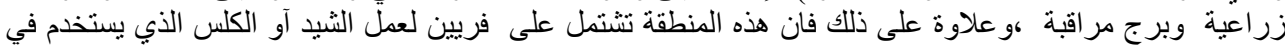

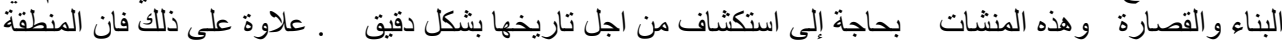




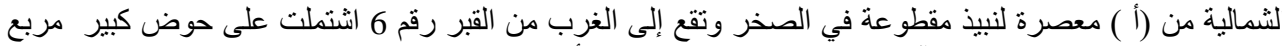

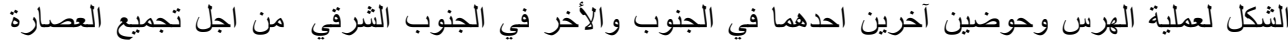

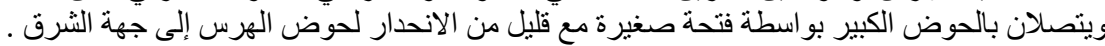

إعداد محمد غياظة بالنة

مدير آثار محافظة بيت لحم 


\section{SOMMARIO}

DipartimENTo SCIENZE DELl'ANTICHITÀ

SEZIONE di ORIENTALISTICA

\section{VICINO ORIENTE \\ XIX - 2015}

L. Nigro - Bethlehem in the Bronze and lron Ages
in the light of recent discoveries by the Palestinian MOTA-DACH

$\checkmark$. Pisaniello - Parallel passages among Hittite-Luwian rituals:

for the restoration of $K U B 35.146$

F. Spagnoli - Una testa di sileno in bronzo da Mozia

N. Chiaren

dall Area sacra del Kothon a Mozia

G. Labisi - al-Fudayn: an Umayyad residence in Northern Jordan

P. Buzi - Early Christianity in the Fayyūm: the new contribution of archaeology

I. Materia - Preliminary notes on the ware depicted on the ceiling

of the Cappella Palatina in Palermo

S. Autiero - Indian Ocean trade:

a reassessment of the pottery find
$\left(3^{\text {rd }}\right.$ century $B C-S^{S^{t h}}$ century $\left.A D\right)$

M.M. Jamhawi - N. Al-Shakarchi - I. Al-Hashimi

Assessment of tourists' satisfaction in the downtown of Amman

SCAVI E RICERCHE

L. Nigro - C. Fiaccavento - M. Jaradat - J. Yasine

A

L. Nigro - D. Montanari - M. Ghayyada - J. Yasine

A Middle Bronze and Iron Age necropolis near Bethlehem (Palestine)

L. Nigro - G. Ripepi - I. Hamdan - J. Yasine

15 Interim Report

and valorization of archaeological heritage

R. Francia - L'archivio di tavolette del complesso B-C-H di Büyükkale

organizazione degli archivi reali ittiti. Considerazioni preliminari

V. Pisaniello - La collezione di tavolette del complesso B-C-H di Büyükkale

T. De Vincenzi - L'archivio di tavolette del complesso B-C-H
sull'acropoli di Büyükkale

Museo del Vicino Oriente, Egitto e Mediterraneo

L. Nigro - Il nuovo allestimento del Museo del Vicino Oriente,

Egitto e Mediterraneo della Sapienza

D. Montanari - Bollettino delle attività del Museo del Vicino Oriente,

Egito e Meditraneo della Sapienza, anno 2015

RECENSIONI

A. Orsingher - E. PAPPA (2013), Early Iron Age Exchange in the West:

(Ancient Near Eastern Studies Supplement Series 43)

Leuven - Paris - Walpole 2013, MA.: Peeters $\frac{1}{2}$

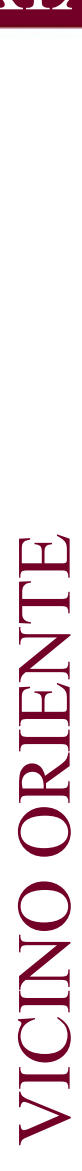

345

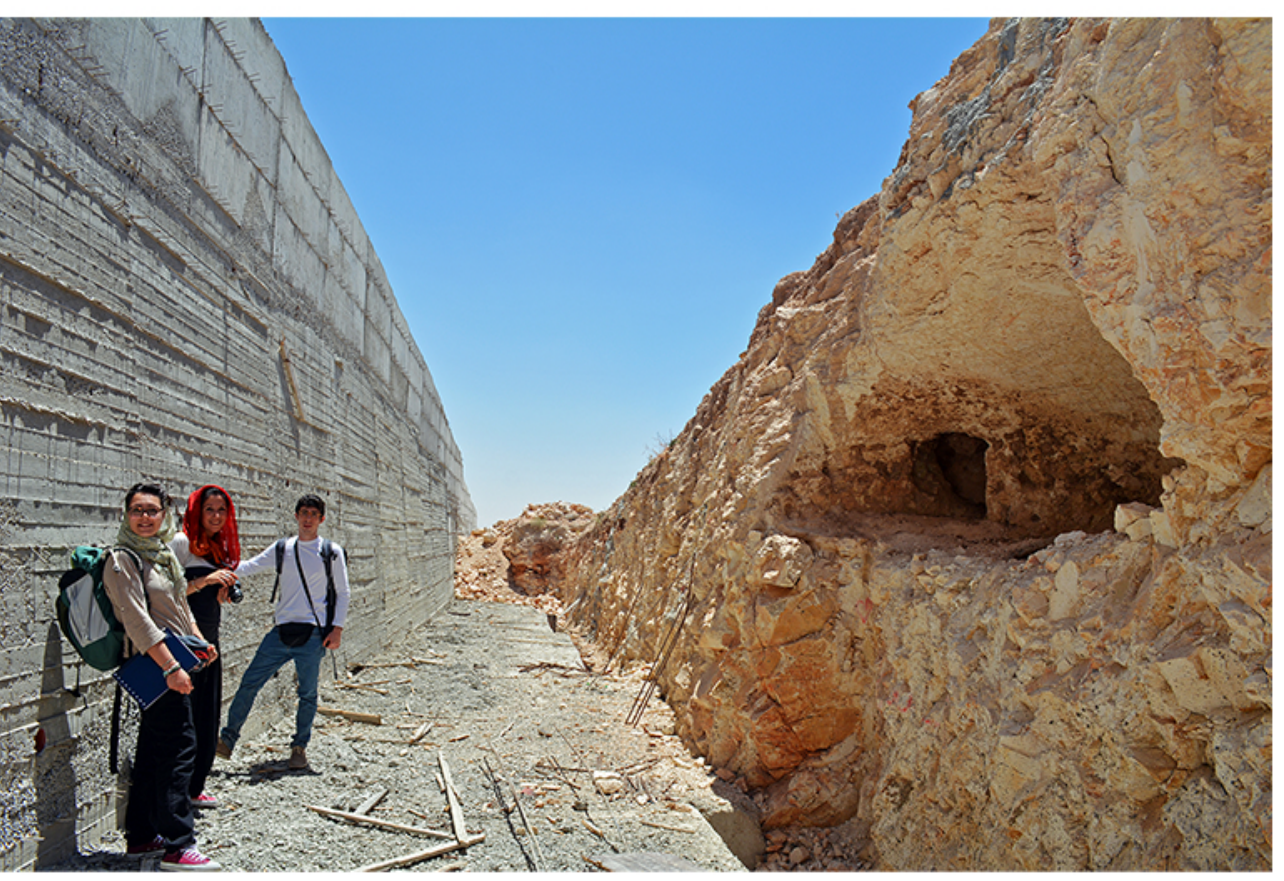

ROMA 2015 


\section{VICINO ORIENTE XIX - 2015}


VICINO ORIENTE

SAPIENZA UNIVERSITÀ DI ROMA

DIPARTIMENTO SCIENZE DELL'ANTICHITÀ

SEZIONE DI ORIENTALISTICA

Scientific Editor: Lorenzo Nigro

International Scientific Committee: Brian Rose, Frank Braemer, Mounir Fantar, Piero Bartoloni, Thomas Schaefer, Zeidan Kafafi

National Scientific Committee: Carlo Giovanni Cereti, Maria Vittoria Fontana, Sebastiano Tusa, Massimiliano Marazzi

Editorial Board: Daria Montanari, Chiara Fiaccavento

Tipografia: SK7 - Roma

ISSN 0393-0300

Rivista con comitato di referee

Journal with international referee system

www.lasapienzatojericho.it/SitoRivista/Journal/Rivista.php

In copertina: Tomba B9, necropoli di Khalet al-Jam’a (Betlemme). 
VICINO ORIENTE

SAPIENZA UNIVERSITÀ DI ROMA

DIPARTIMENTO SCIENZE DELL'ANTICHITÀ

SEZIONE DI ORIENTALISTICA

\section{SOMMARIO}

ARTICOLI

L. Nigro - Bethlehem in the Bronze and Iron Ages

in the light of recent discoveries by the Palestinian MOTA-DACH

V. Pisaniello - Parallel passages among Hittite-Luwian rituals:

for the restoration of KUB 35.146

F. Spagnoli - Una testa di sileno in bronzo da Mozia

N. Chiarenza - Una matrice per terrecotte con sileno dall'Area sacra del Kothon a Mozia

G. Labisi - al-Fudayn: an Umayyad residence in Northern Jordan

P. Buzi - Early Christianity in the Fayyūm: the new contribution of archaeology

I. Materia - Preliminary notes on the ware depicted on the ceiling

of the Cappella Palatina in Palermo

S. Autiero - Indian Ocean trade:

a reassessment of the pottery finds from a multidisciplinary point of view ( $3^{\text {rd }}$ century $B C-5^{\text {th }}$ century $\left.A D\right)$

M.M. Jamhawi - N. Al-Shakarchi - I. Al-Hashimi

Assessment of tourists' satisfaction in the downtown of Amman

SCAVI E RICERCHE

L. Nigro - C. Fiaccavento - M. Jaradat - J. Yasine Archaeology from A to Z: Abu Zarad, an ancient town in the heartland of Palestine

L. Nigro - D. Montanari - M. Ghayyada - J. Yasine

Khalet al-Jam'a. A Middle Bronze and Iron Age necropolis near Bethlehem (Palestine) 185 
VICINO ORIENTE

SAPIENZA UNIVERSITÀ DI ROMA

DIPARTIMENTO SCIENZE DELL'ANTICHITÀ

SEZIONE DI ORIENTALISTICA

L. Nigro - G. Ripepi - I. Hamdan - J. Yasine

The Jericho Oasis Archaeological Park - 2015 Interim Report.

Italian-Palestinian Cooperation for protection

and valorization of archaeological heritage

R. Francia - L'archivio di tavolette del complesso B-C-H di Büyükkale

e l'organizzazione degli archivi reali ittiti. Considerazioni preliminari

V. Pisaniello - La collezione di tavolette del complesso B-C-H di Büyükkale

T. De Vincenzi - L'archivio di tavolette del complesso B-C-H sull'acropoli di Büyükkale

Museo del Vicino ORIente, Egitto e MediterRaneo

L. Nigro - Il nuovo allestimento del Museo del Vicino Oriente,

Egitto e Mediterraneo della Sapienza

D. Montanari - Bollettino delle attività del Museo del Vicino Oriente,

Egitto e Mediterraneo della Sapienza, anno 2015

\section{RECENSIONI}

A. Orsingher - E. PAPPA (2013), Early Iron Age Exchange in the West:

Phoenicians in the Mediterranean and the Atlantic

(Ancient Near Eastern Studies Supplement Series 43),

Leuven - Paris - Walpole 2013, MA.: Peeters 